\title{
The Effect of Modified Lysozyme Treatment on the Microflora, Physicochemical and Sensory Characteristics of Pork Packaged in Preservative Gas Atmospheres
}

\author{
Renata Cegielska-Radziejewska ${ }^{1, *}$, Tomasz Szablewski ${ }^{1}$ (D, Elżbieta Radziejewska-Kubzdela ${ }^{2}$, \\ Lukasz Tomczyk $^{1}$ (D), Agata Biadała ${ }^{1}$ and Grzegorz Leśnierowski ${ }^{1}$ (D) \\ 1 Department of Food Quality and Safety Management, Faculty of Food Science and Nutrition, \\ Poznań University of Life Sciences, Wojska Polskiego 31, 60-637 Poznań, Poland; \\ tomasz.szablewski@up.poznan.pl (T.S.); tomczyk@up.poznan.pl (Ł.T.); agata.biadala@up.poznan.pl (A.B.); \\ grzegorz.lesnierowski@up.poznan.pl (G.L.) \\ 2 Department of Food Technology of Plant Origin, Faculty of Food Science and Nutrition, Poznań University of \\ Life Sciences, Wojska Polskiego 31, 60-637 Poznań, Poland; elzbieta.radziejewska-kubzdela@up.poznan.pl \\ * Correspondence: renata.cegielska-radziejewska@up.poznan.pl; Tel.: +48-618487323
}

Citation: Cegielska-Radziejewska, R.; Szablewski, T.;

Radziejewska-Kubzdela, E.; Tomczyk,

Ł.; Biadała, A.; Leśnierowski, G. The

Effect of Modified Lysozyme

Treatment on the Microflora,

Physicochemical and Sensory Characteristics of Pork Packaged in Preservative Gas Atmospheres. Coatings 2021, 11, 488. https:// doi.org/10.3390/coatings11050488

Academic Editor: Raffaele Porta

Received: 25 March 2021

Accepted: 19 April 2021

Published: 22 April 2021

Publisher's Note: MDPI stays neutral with regard to jurisdictional claims in published maps and institutional affiliations.

Copyright: (C) 2021 by the authors Licensee MDPI, Basel, Switzerland. This article is an open access article distributed under the terms and conditions of the Creative Commons Attribution (CC BY) license (https:// creativecommons.org/licenses/by/ $4.0 /)$

\begin{abstract}
The aim of the study was to investigate the effect of modified lysozyme on the microflora, physicochemical and sensory characteristics of pork loin packaged in modified atmospheres and stored at $4 \pm 1{ }^{\circ} \mathrm{C}$. Different gas compositions (M1 65:25:10 $\mathrm{O}_{2}: \mathrm{CO}_{2}: \mathrm{N}_{2} ; \mathrm{M} 2$ 50:40:10 $\mathrm{O}_{2}: \mathrm{CO}_{2}: \mathrm{N}_{2} ; \mathrm{M} 3$ 80:20 $\mathrm{O}_{2}: \mathrm{CO}_{2}$ ) were used. The microbiological parameters (APC, Enterobacteriaceae, Pseudomonas spp., lactic acid bacteria), physicochemical indexes ( $\mathrm{pH}$, colour) as well as a sensory attribute, i.e., aroma were analysed. Meat samples were tested after five, 12, 19, 23, and 28 days of storage. Changes in the qualities of pork were determined throughout the storage. The proportions of polymeric forms, hydrolytic activity and hydrophobicity were determined in the lysozyme preparation. Modified lysozyme exhibited higher hydrophobicity and lower hydrolytic activity than lysozyme monomer. The colour parameters $\mathrm{L}^{*}$ and $\mathrm{a}^{*}$ were not considerably affected by the addition of modified lysozyme. The sample with the modified lysozyme was given the highest score for aroma. In comparison with the monomer, the modified lysozyme exhibited greater antibacterial effect, especially against Pseudomonas and Enterobacteriaceae. Microbial growth rates in the sample with modified lysozyme, packaged in an atmosphere with the highest content of $\mathrm{CO}_{2}$ (total plate count $4.59 \log \mathrm{CFU} / \mathrm{cm}^{2}$; moulds and yeasts $2.17 \log \mathrm{CFU} / \mathrm{cm}^{2}$ ) were lower than those observed in the sample without lysozyme packed under M1 and M3 $\left(20-25 \% \mathrm{CO}_{2}\right)$. The use of an atmosphere with gas composition and modified lysozyme considerably extended the shelf life of pork. The combination of the atmosphere with the highest content of carbon dioxide $\left(50 \% \mathrm{O}_{2}, 40 \% \mathrm{CO}_{2}, 10 \%\right.$ $\mathrm{N}_{2}$ ) and modified lysozyme resulted in the best effect. This strategy extended the shelf-life by more than $20 \%$, as compared with the control sample without lysozyme, packaged in an atmosphere of $50: 40: 10 \mathrm{O}_{2}: \mathrm{CO}_{2}: \mathrm{N}_{2}$.
\end{abstract}

Keywords: lysozyme; packaging; modification; bacteriostatic activity; meat

\section{Introduction}

Meat and processed meat products are a favourable environment for the growth of various bacteria, which spoil food, as well as pathogenic bacteria, which cause serious food poisonings. Nowadays, consumers expect high-quality food with extended shelf life but without chemical additives. Therefore, natural preservatives are a good way to extend the shelf life of food [1-7]. One of them is lysozyme (E.C.3.2.17, N-acetyl-muramichydrolase), an enzyme with bacteriostatic and bactericidal properties, which is commonly found in nature. Egg white is a rich and easily accessible source of this enzyme. It is characterised by stability and activity within a wide range of temperatures and $\mathrm{pH}$ 
values. The lysozyme monomer, which is the basic form of the enzyme, is widely used to preserve cheese, wine, meat, fruit and vegetables [7-9]. The antibacterial activity of this form of the enzyme is mostly limited to Gram-positive bacteria due to their cell wall structure. However, it is Gram-negative bacteria that constitute a considerable proportion of both pathogenic bacteria and those that cause food spoilage during storage. This group of bacteria is additionally protected by components covering the peptidoglycan layer, such as polypeptides, lipoproteins and lipopolysaccharides. The cell wall structure is an essential, but not the only factor influencing the susceptibility of bacteria to the action of the enzyme. Research has shown that the spectrum of antibacterial activity of lysozyme can be extended by modification of the enzyme structure and its properties. As a result of thermal, chemical and thermochemical modification, dimer and oligomeric forms of lysozyme are obtained, which exhibit stronger inhibitory effect against Gram-negative bacteria [10-13]. It is possible to achieve higher antibacterial effectiveness of various preservatives by combining their action with other agents or preservative methods [14-16]. Modified atmosphere packaging is an effective method of extending the shelf life of food, including meat and processed meat products [16]. The choice of the right composition of gases determines both the quality and safety of packaged products. Among commonly used gases, it is carbon dioxide that mainly inhibits the growth of aerobic bacteria, which spoil the meat. Carbon dioxide extends the lag phase and reduces the rate of bacterial growth $[17,18]$.

So far, researchers have mainly assessed the antibacterial properties of the native form of lysozyme. There have been few studies on the possibility to use the properties of the modified enzyme to extend the shelf life of food, including meat, especially meat packaged in a modified atmosphere. Lysozyme as an antimicrobial enzyme can be used in active packaging systems $[7,19,20]$. For this reason, the aim of this study was to assess the effects of modified lysozyme and monomer on the microflora, colour, aroma, and $\mathrm{pH}$ of pork packaged in a modified atmosphere with diversified gas composition.

\section{Materials and Methods}

\subsection{Materials}

\subsubsection{Lysozyme Modification}

Lysozyme obtained from the albumin of chicken eggs (Belovo Company, Bastogne, Belgium) underwent thermochemical modification. A lysozyme solution of $\mathrm{pH} 4.0$ was heated at $70{ }^{\circ} \mathrm{C}$ in a water bath type 1083 (Gesellschaft für Labortechnik, Burgwedel, Germany) for $15 \mathrm{~min}$ and then it was immediately cooled in ice water. An adequate amount of $\mathrm{H}_{2} \mathrm{O}_{2}$ was added to the solution to make a $2 \%$ concentration. The lysozyme solution was stored for 6 days at $7{ }^{\circ} \mathrm{C} \pm 1{ }^{\circ} \mathrm{C}$. The preparation produced by thermochemical modification was marked as P. After modification, the enzyme preparation was lyophilised in a GT3 Leybold-Heraeus freeze dryer (Heraeus Instruments, Hanau, Germany). The hydrolytic activity and surface hydrophobicity of the monomer and modified lysozyme were measured. The proportions of oligomeric forms in the lysozyme preparation were measured after modification.

\subsubsection{Meat and Experimental Design}

Pork loin with a fat content of $6.2 \% \pm 0.1 \%$, measured by Soxhlet extraction [21] was obtained directly from a meat processing plant and used as a raw material for analyses. The meat was aseptically sliced into 15-mm-thick chops, on the surface of which $2 \mathrm{~mL}$ of $5 \%$ aqueous solutions of the monomer and modified lysozyme were applied. Sterilised distilled water was added to the control sample. All the meat was divided into three groups: samples with the lysozyme monomer $(\mathrm{M})$, thermochemically modified lysozyme preparations $(\mathrm{P})$, and control samples without the enzyme $(\mathrm{C})$.

All the samples were placed aseptically on $205 \times 160 \times 60 \mathrm{~mm}^{3}$ polypropylene trays with an oxygen transmission rate of $7-8 \mathrm{~cm}^{3} / \mathrm{m}^{2} / 24 \mathrm{~h}$. Selected atmosphere concentrations: M1:(65\% O $\left.2,25 \% \mathrm{CO}_{2}, 10 \% \mathrm{~N}_{2}\right), \mathrm{M} 2:\left(50 \% \mathrm{O}_{2}, 40 \% \mathrm{CO}_{2}, 10 \% \mathrm{~N}_{2}\right), \mathrm{M} 3:\left(80 \% \mathrm{O}_{2}, 20 \% \mathrm{CO}_{2}\right)$ 
and air atmosphere were entered into the packages prior to thermal sealing with a gas packing device (WITT KM 100/200-3MEM gas mixer (Witt-Gasetechnik, Witten, Germany); Multivac T200 packaging machine (Wolfertschwenden, Germany). The trays were sealed with Opalen HB 55 packaging film with oxygen permeability of $35 \mathrm{~cm}^{3} / \mathrm{m}^{2} / 24 \mathrm{~h}$ atm at $23{ }^{\circ} \mathrm{C}$ and $85 \% \mathrm{RH}$ (according to data provided by the film manufacturer-Bemis, Soignies, Belgium) and they were stored at $4 \pm 1{ }^{\circ} \mathrm{C}$. The samples were assigned to one of nine treatments: M1C: $65 \% \mathrm{O}_{2}, 25 \% \mathrm{CO}_{2}, 10 \% \mathrm{~N}_{2}$, control; M1M: $65 \% \mathrm{O}_{2}, 25 \% \mathrm{CO}_{2}, 10 \% \mathrm{~N}_{2}$, monomer; M1P: $65 \% \mathrm{O}_{2}, 25 \% \mathrm{CO}_{2}, 10 \% \mathrm{~N}_{2}$, modified lysozyme; $\mathrm{M} 2 \mathrm{C}: 50 \% \mathrm{O}_{2}, 40 \% \mathrm{CO}_{2}$, $10 \% \mathrm{~N}_{2}$, control; M2M: $50 \% \mathrm{O}_{2}, 40 \% \mathrm{CO}_{2}, 10 \% \mathrm{~N}_{2}$, monomer; $\mathrm{M} 2 \mathrm{P}: 50 \% \mathrm{O}_{2}, 40 \% \mathrm{CO}_{2}$, $10 \% \mathrm{~N}_{2}$, modified lysozyme; M3C: $80 \% \mathrm{O}_{2}, 20 \% \mathrm{CO}_{2}$, control; $\mathrm{M} 3 \mathrm{M}: 80 \% \mathrm{O}_{2}, 20 \% \mathrm{CO}_{2}$, monomer; M3P: $80 \% \mathrm{O}_{2}, 20 \% \mathrm{CO}_{2}$, modified lysozyme preparation.

The samples were taken for analysis immediately after inoculation (fresh pork) and again after 5, 12, 19, 23 and 28 days of refrigerated storage. During storage the samples were analysed microbiologically, the colour and odour of the meat were evaluated, and $\mathrm{pH}$ was measured.

\subsection{Methods}

\subsubsection{Hydrolytic Activity}

The hydrolytic activity of lysozyme was measured by monitoring the decrease in the turbidity of a suspension of Micrococcus lysodeikticus (Sigma-Aldrich, St. Louis, MO, USA) cells at $450 \mathrm{~nm}$ [22]. The activity was presented as the rate of decrease in absorbance per $\mathrm{min}$ of the initial rate of reaction $(\Delta \mathrm{abs} / \mathrm{min})$.

\subsubsection{Electrophoresis}

Electrophoresis on polyacrylamide gel was used to determine the content of polymeric forms of modified lysozyme (SE-600 apparatus, Hoefer Scientific Instruments, Holliston, MA, USA). SDS-PAGE and $6 \%$ stacking gels at a current of $60 \mathrm{~mA}$ and $12.5 \%$ separating gels at $90 \mathrm{~mA}$ were used [22,23]. The gels were stained with $0.025 \%$ Coomassie Brilliant Blue R solution. The following standards were used: lysozyme $14.6 \mathrm{kDa}$ (Sigma-Aldrich, Munich, Germany), Lydium KLP 28 kDa (Nika Health Product, Parsko, Poland) and hen egg albumen $45 \mathrm{kDa}$ (Sigma-Aldrich, Munich, Germany). The quantitative proportions of individual forms of lysozyme were determined densitometrically with the TotalLab Quant software (Nonlinear Dynamics Ltd., Durham, NC, USA).

\subsubsection{Surface Hydrophobicity}

Surface hydrophobicity was determined according to the procedure described by Kato \& Nakai [24] and Li-Chan et al. [25]. Aniline 1-naphthalenesulfonic acid (ANS, Sigma-Aldrich, Munich, Germany) was used for measurements. An LS 55 luminescence spectrometer (Perkin Elmer, Norwalk, CT, USA) with an output wavelength of $\lambda=390 \mathrm{~nm}$ and emitter wavelength of $\lambda=470 \mathrm{~nm}$ was applied. Lysozyme solutions $(0.01 \%)$ and dilutions were prepared in a phosphate buffer ( $\mathrm{pH}$ 6.0). A volume of $3 \mathrm{~mL}$ collected from each dilution and $15 \mu \mathrm{L}$ of ANS dissolved in methanol were added. After $15 \mathrm{~s}$ the fluorescence intensity was measured. The surface hydrophobicity was equal to the slope coefficient for the curve of fluorescence intensity versus protein concentration.

\subsubsection{Microbiological Analyses}

Samples for microbiological analyses were collected with swabs and sterile USDA templates (Noack) from the meat surface and transferred into $100 \mathrm{~mL}$ of $0.1 \%$ sterile pepton diluents (Bacteriological Pepton, Oxoid, UK) so as to obtain a bacterial sample from $1 \mathrm{~cm}^{2}$. A ten-fold dilution was prepared. The microbiological analyses were conducted according to the International Organization for Standardization (ISO) reference methods [26-29]. Bacterial counts were expressed as $\log 10 \mathrm{CFU} / \mathrm{g}$. The total viable aerobic bacterial count was determined on Standard Plate Count Agar (CM 463, Oxoid, Basingstoke, UK) after $72 \mathrm{~h}$ incubation at $30^{\circ} \mathrm{C}$. The count of Enterobacteriaceae rods was measured on melted selective 
VRBG medium (P-0256, BTL, Łódź, Poland) after incubation at $37^{\circ} \mathrm{C}$ for $24-48 \mathrm{~h}$. The count of Pseudomonas was determined on solid Pseudomonas Agar (CM 0559, Oxoid, Basingstoke, UK) supplemented with Pseudomonas CFC Selective Agar Supplement (SR 0103, Oxoid, Basingstoke, UK) after incubation at $30^{\circ} \mathrm{C}$ for $48 \mathrm{~h}$. The count of lactic acid bacteria was measured on MRS agar (de Man, Rogosa and Sharpe) (CM 0361, Oxoid, Basingstoke, UK). MRS agar was overlaid with the melted medium and incubation at $30^{\circ} \mathrm{C}$ for $48-72 \mathrm{~h}$ was applied. An oxidase test was used to measure the count of lactic acid bacteria (MBO 266, Oxoid, Basingstoke, UK). The counts of yeast and moulds were determined on Dichloran Rose Bengal Chloramphenicol (DRBC) agar (BTL, Łódź, Poland) after incubation at $25^{\circ} \mathrm{C}$ for 5 days. The microbiological analysis was conducted in four replicates (twice).

\subsubsection{Sensory Evaluation}

An experienced trained panel evaluated sensory changes in the meat aroma. Eight people (four women and four men, aged 30 and 55) participated in the evaluation. The panel consisted of the staff of the Institute of Meat Technology and Department of Food Quality Management, trained in basic methods of sensory analysis and qualified as experts according to the standard [30]. Before to the sensory evaluation the panelists had three training sessions to familiarize themselves with the characteristics of product and scoring methods. The panel members did not change throughout the study. The products were evaluated in a sensory laboratory at room temperature. On opening bags with meat, the product underwent sensory evaluation. The aroma was rated with a five-point scale, where 5 meant very good aroma, whereas 1 indicated poor aroma. The following criteria were applied to evaluate the meat aroma on the five-point scale: 5 -intrinsic aroma, characteristic of fresh meat, desirable; 4-hardly detectable changes in aroma; 3-undesirable aroma, detectable changes, slightly altered; 2-distinctly altered aroma of low intensity; 1-markedly altered, putrid, very intense aroma. The results of sensory analysis were expressed as means of three separate experimental determinations for each sample.

\subsubsection{Colour Measurements}

The meat surface colour was measured with a Chromameter 200b (Minolta, Osaka, Japan), with the $L^{*}, a^{*}, b^{*}$ coordinates of the CIELAB model [31]. Chroma $\left(C^{*}\right)$ and hue angle $\left(h^{*}\right)$ parameters were calculated [32]: $C^{*}=\left[\left(a^{* 2}+b^{* 2}\right)^{1 / 2}\right] ; h^{*}=\left[\left(b^{*} / a^{*}\right) \tan ^{-1}\right]$. The apparatus was calibrated before each measurement. Six measurements were taken, and the averages were used in the statistical analysis.

\subsection{7. $\mathrm{pH}$ Measurement}

The meat $\mathrm{pH}$ was measured with a $\mathrm{CP}-505 \mathrm{pH}$-meter and a spear tip glass electrode EPS-1 (Elmetron, Zabrze, Poland) in the meat homogenates $(10 \mathrm{~g}$ meat: $40 \mathrm{~mL}$ distilled water). These tests were conducted in triplicates.

\subsubsection{Statistical Analysis}

The statistical tests were performed STATISTICA 13.1 software (StatSoft, Tulusa, OK, USA). The experiments were replicated twice. Three or four measurements in each replicate were analysed. The replicates were separated from each other. The counts of bacteria were transformed into $\log$ CFU/g for data analysis. Analysis of variance (ANOVA) and Fisher's least significant difference (LSD) were used to determine the significance of the results. Principal components analysis was applied to the mean quality scores to determine the interrelation between quality attributes and samples.

\section{Results and Discussion}

\subsection{Lysozyme}

The modification resulted in a lysozyme of lower hydrolytic activity $(1010 \mathrm{U} / \mathrm{mg}$ vs. $17,800 \mathrm{U} / \mathrm{mg}$ ) and higher hydrophobicity (40,620 vs. 880$)$ than the monomer. After modification, the lysozyme preparation contained the monomer and oligomeric forms, 
including 37\% dimer and 34\% trimer. This result is consistent with the findings of earlier studies observations on the modification of lysozyme. Membrane, thermal and thermochemical modifications resulted in the formation of dimer and oligomeric forms of the enzyme. In consequence, the physicochemical and antibacterial properties of the lysozyme changed $[33,34]$. The modification also changed the lysozyme molecule structure, which resulted in an exposure of tryptophan units and an increase in the hydrophobic area [9].

\subsection{Microbiological Changes}

The aerobic plate count (APC) in all the samples is shown in Table 1. After five days of storage the count of aerobic bacteria decreased, but then it increased, depending on the composition of gases in the package and the form of lysozyme. The lowest count of bacteria was noted in the samples with modified lysozyme (M1P, M2P, M3P), regardless of the type of atmosphere used. In comparison with the control sample, the addition of modified lysozyme inhibited the growth of aerobic bacteria during 28 days of refrigerated storage. Depending on the type of atmosphere, after 19 days of meat storage the APC difference between the control sample and the sample with modified lysozyme was 1.93-3.21 log $\mathrm{CFU} / \mathrm{cm}^{2}$. During storage the count of aerobic bacteria in the meat samples with the lysozyme monomer was lower than in the control sample. In earlier studies, researchers also observed that modified lysozyme limited the growth of aerobic bacteria in comminuted pork [35].

Table 1. The effect of lysozyme and modified atmosphere on the aerobic plate counts (APC) and Pseudomonas spp. in pork stored at $4{ }^{\circ} \mathrm{C} \pm 1{ }^{\circ} \mathrm{C}$.

\begin{tabular}{|c|c|c|c|c|c|c|}
\hline \multirow{3}{*}{ Treatment } & \multicolumn{6}{|c|}{ Population $\left[\log \mathrm{CFU} / \mathrm{cm}^{2} \pm \mathrm{SD}\right]$} \\
\hline & \multicolumn{6}{|c|}{ Storage Time [Days] } \\
\hline & 0 & 5 & 12 & 19 & 23 & 28 \\
\hline \multicolumn{7}{|c|}{ Aerobic plate count } \\
\hline M1C & ${ }^{\text {B }} 2.47 \pm 0.11_{\mathrm{a}}$ & A $1.57 \pm 0.08_{c}$ & $C_{3.86} \pm 0.06 \mathrm{~g}$ & D $5.67 \pm 0.12 \mathrm{e}$ & ${ }^{\mathrm{E}} 5.91 \pm 0.04 \mathrm{~g}$ & ${ }^{F} 6.60 \pm 0.12 \mathrm{~d}$ \\
\hline M1M & В $2.47 \pm 0.11 \mathrm{a}$ & A $1.58 \pm 0.07_{c}$ & ${ }^{B} 2.64 \pm 0.06_{f}^{\circ}$ & $C_{3.61 \pm 0.12}$ & D $5.45 \pm 0.39_{\mathrm{ef}}^{\circ}$ & ${ }^{\mathrm{E}} 6.44 \pm 0.31 \mathrm{~d}$ \\
\hline M1P & $\mathrm{C}_{2.47 \pm 0.11_{\mathrm{a}}}$ & $\mathrm{A}_{1.22 \pm 0.11_{\mathrm{b}}}$ & B $1.69 \pm 0.03_{c}$ & $C_{2} 2.46 \pm 0.06_{b}$ & $\mathrm{D}_{4} 4.66 \pm 0.23_{\mathrm{c}}$ & E $5.39 \pm 0.09 c$ \\
\hline $\mathrm{M} 2 \mathrm{C}$ & $\mathrm{C}_{2.47 \pm 0.11 \mathrm{a}}$ & ${ }^{\mathrm{A}} 1.48 \pm 0.04_{\mathrm{c}}$ & В $2.09 \pm 0.08 \mathrm{e}$ & $\mathrm{D}_{3.69 \pm 0.09} \mathrm{c}$ & ${ }^{\mathrm{E}} 4.78 \pm 0.17_{c}$ & $\mathrm{~F} 5.55 \pm 0.11_{\mathrm{c}}$ \\
\hline $\mathrm{M} 2 \mathrm{M}$ & В $2.47 \pm 0.11$ a & A $1.30 \pm 0.05_{b}$ & B $1.89 \pm 0.04 \mathrm{~d}$ & $\mathrm{C}_{2.33} \pm 0.05_{\mathrm{b}}$ & $\mathrm{D}_{3.03} \pm 0.05_{\mathrm{b}}$ & ${ }^{\mathrm{E}} 4.96 \pm 0.06_{b}$ \\
\hline M2P & ${ }^{\mathrm{E}} 2.47 \pm 0.11_{\mathrm{a}}$ & A $1.00 \pm 0.04 \mathrm{a}$ & B $1.31 \pm 0.03 \mathrm{a}$ & $\mathrm{C}_{1.55 \pm 0.09 \mathrm{a}}$ & D $1.99 \pm 0.04 \mathrm{a}$ & $\mathrm{F} 4.59 \pm 0.03 \mathrm{a}$ \\
\hline M3С & В $2.47 \pm 0.11 \mathrm{a}$ & A $1.91 \pm 0.11 \mathrm{e}$ & $\mathrm{C}_{4.31 \pm 0.18_{\mathrm{h}}}$ & D $5.49 \pm 0.11 \mathrm{e}$ & ${ }^{\mathrm{E}} 5.80 \pm 0.04 \mathrm{fg}$ & ${ }^{\mathrm{F}} 6.68 \pm 0.05 \mathrm{~d}$ \\
\hline $\mathrm{M} 3 \mathrm{M}$ & B $2.47 \pm 0.11_{\mathrm{a}}$ & ${ }^{\mathrm{A}} 1.88 \pm 0.08 \mathrm{e}$ & ${ }^{B} 2.65 \pm 0.03_{f}$ & $C_{4.29} \pm 0.07 \mathrm{~d}$ & D $5.27 \pm 0.28 \mathrm{de}$ & ${ }^{\mathrm{E}} 6.67 \pm 0.05 \mathrm{~d}$ \\
\hline M3P & В $2.47 \pm 0.11_{\mathrm{a}}$ & A $1.02 \pm 0.05 \mathrm{a}$ & A $1.07 \pm 0.09 \mathrm{a}$ & $\mathrm{C}_{3.56 \pm 0.06 \mathrm{c}}$ & $\mathrm{D}_{4.83} \pm 0.05 \mathrm{~cd}$ & E $5.40 \pm 0.13_{c}$ \\
\hline \multicolumn{7}{|c|}{ Pseudomonas spp. } \\
\hline M1C & B $2.09 \pm 0.15 \mathrm{a}$ & A $1.79 \pm 0.03$ de & $\mathrm{C}_{3.84 \pm 0.09 \mathrm{f}}$ & D $5.71 \pm 0.12 \mathrm{~g}$ & $\mathrm{D} 5.82 \pm 0.02 \mathrm{~d}$ & ${ }^{\mathrm{E}} 6.32 \pm 0.03 \mathrm{e}$ \\
\hline M1M & в $2.09 \pm 0.15 \mathrm{a}$ & A $1.58 \pm 0.07 c$ & $\mathrm{C}_{2.68 \pm 0.06_{\mathrm{d}}}$ & $\mathrm{D} 4.00 \pm 0.21 \mathrm{e}$ & ${ }^{\mathrm{E}} 5.57 \pm 0.40_{\mathrm{d}}^{\mathrm{d}}$ & F $6.44 \pm 0.09 \mathrm{e}$ \\
\hline M1P & $C_{2.09} \pm 0.15 \mathrm{a}$ & $\mathrm{A} 1.07 \pm 0.05 \mathrm{a}$ & В $1.59 \pm 0.09{ }_{b}$ & D $2.54 \pm 0.06_{b c}$ & ${ }^{\mathrm{E}} 4.72 \pm 0.13_{c}$ & F $5.10 \pm 0.03_{b}$ \\
\hline M2C & В $2.09 \pm 0.15 \mathrm{a}$ & $\mathrm{A} 1.47 \pm 0.05_{c}$ & $C^{C} 2.53 \pm 0.05 \mathrm{~d}$ & $\mathrm{C}_{2.74} \pm 0.08_{\mathrm{c}}$ & D $4.69 \pm 0.17 c$ & E $5.01 \pm 0.04 \mathrm{~b}$ \\
\hline M2M & В $2.09 \pm 0.15 \mathrm{a}$ & A $1.37 \pm 0.14_{b c}$ & B $1.94 \pm 0.03_{c}$ & $\mathrm{C}_{2.42 \pm 0.09} \mathrm{~b}_{\mathrm{b}}$ & $\mathrm{D}_{2.91} \pm 0.03_{\mathrm{b}}$ & ${ }^{\mathrm{E}} 4.74 \pm 0.03 \mathrm{a}$ \\
\hline M2P & $C_{2.09} \pm 0.15 \mathrm{a}$ & A $1.12 \pm 0.08 \mathrm{a}$ & A $1.12 \pm 0.13 \mathrm{a}$ & B $1.78 \pm 0.04 \mathrm{a}$ & B $1.79 \pm 0.04 \mathrm{a}$ & $\mathrm{D}_{4.65} \pm 0.07 \mathrm{a}$ \\
\hline M3C & A $2.09 \pm 0.15 \mathrm{a}$ & A $1.95 \pm 0.04 \mathrm{e}$ & B $3.94 \pm 0.05_{\mathrm{f}}$ & $C_{5.76} \pm 0.01 \mathrm{~g}$ & D $5.94 \pm 0.02 \mathrm{~d}$ & ${ }^{\mathrm{E}} 6.63 \pm 0.06_{\mathrm{f}}$ \\
\hline M3M & В $2.09 \pm 0.15 \mathrm{a}$ & $\mathrm{A}^{\mathrm{A}} 1.53 \pm 0.18_{\mathrm{c}}$ & $C_{2} 2.65 \pm 0.14_{\mathrm{d}}$ & $\mathrm{D} 4.63 \pm 0.15_{\mathrm{f}}$ & E $5.65 \pm 0.12 \mathrm{~d}$ & F $5.78 \pm 0.03 \mathrm{~d}$ \\
\hline М3Р & A $2.09 \pm 0.15 \mathrm{a}$ & A $1.19 \pm 0.14 \mathrm{ab}$ & B $3.59 \pm 0.09 \mathrm{e}$ & ${ }^{C} 3.59 \pm 0.09 \mathrm{~d}$ & D $4.70 \pm 0.04_{c}$ & ${ }^{\mathrm{E}} 5.38 \pm 0.09 \mathrm{c}$ \\
\hline
\end{tabular}

All values are mean \pm SD of the replicates (8); (a-f) means with the same subscript are not different $(p>0.05)$-effect of treatments; (A-F) means with the same superscript are not different $(p>0.05)$-effect of time; (M1—65:25:10 $\mathrm{O}_{2}: \mathrm{CO}_{2}: \mathrm{N}_{2}, \mathrm{M} 2-50: 40: 10 \mathrm{O}_{2}: \mathrm{CO}_{2}: \mathrm{N}_{2} \mathrm{M}_{3}-80: 20$ $\mathrm{O}_{2}: \mathrm{CO}_{2}, \mathrm{C}$-control, $\mathrm{M}$-monomer, $\mathrm{P}$-modified lysozyme).

Regardless of the form of lysozyme, the lowest count of bacteria was noted in the samples of meat packed in M2 atmosphere with the highest content of carbon dioxide. This result is consistent with the findings of other authors, who indicated the antibacterial effect of carbon dioxide, especially at high concentration. Carbon dioxide is used as the main bacteriostatic agent to extend the shelf life of meat packaged in modified atmosphere $[15,18,36,37]$. 
The initial count of Pseudomonas spp. was $2.09 \log \mathrm{CFU} / \mathrm{cm}^{2}$ (Table 1). These are dominant bacteria in meat stored in an air atmosphere at a lower temperature [38]. Pseudomonas are the most numerous part of microbiota in pork packaged in $100 \%$ oxygen [36]. During the storage of the meat the count of Pseudomonas spp. bacteria in the samples with modified lysozyme was lower than in the samples with the monomer. In comparison with the control populations, modified lysozyme significantly inhibited the growth of Pseudomonas spp. during storage. After 19 days of storage the count of Pseudomonas spp. bacteria in samples M1P, M2P and M3P was 2.54, 1.78, and $3.59 \log \mathrm{CFU} / \mathrm{cm}^{2}$, respectively, whereas in the samples without the enzyme it was $5.71,2.74$, and $5.76 \log \mathrm{CFU} / \mathrm{cm}^{2}$. The highest count of Pseudomonas spp. bacteria was found in the samples of meat packed in atmosphere M3P, which had the highest content of oxygen. Labadie [38] reported that the microbial efficacy of carbon dioxide is reduced when oxygen and other gases are present in a package. Regardless of the atmosphere of gases, the lowest count of Pseudomonas spp. was found in the samples with modified lysozyme. During the meat storage the lowest count of bacteria was found in sample M2P with the highest content of carbon dioxide in the package. After 23 days of storage the count of Pseudomonas spp. bacteria in the meat sample with modified lysozyme packaged in atmosphere M2 was $2.9 \mathrm{CFU} / \mathrm{cm}^{2}$ lower than in the control sample. Modified lysozyme was also effective against Pseudomonas spp. bacteria in a study on the storage of unheated and heated ground pork [35]. However, there were no statistically significant differences between the count of Pseudomonas spp. in the control sample of bison meat and the samples immersed in $0.5-2 \%$ lysozyme monomer solutions. The lysozyme monomer reduced the bacterial count only when it was combined with EDTA [39]. The lysozyme monomer was also ineffective against Pseudomonas fluorescens during the storage of refrigerated minced lamb meat [40].

The applied form of lysozyme, the composition of the atmosphere of gases and the meat storage time had a statistically significant effect on the count of bacteria from the Enterobacteriaceae family (Table 2). There were no Enterobacteriaceae bacteria during the storage of meat samples with modified lysozyme, packed in an atmosphere with $40 \%$ carbon dioxide (M2P). The modified lysozyme also inhibited the growth of these bacteria in the meat samples packed in gas atmospheres M1 and M3. After 23 days of storage the count of Enterobacteriaceae in samples M1P and M3P was 2.57 and $2.75 \log \mathrm{CFU} / \mathrm{cm}^{2}$, whereas in control samples M1C and M3C the count amounted to 4.45 and $4.84 \log \mathrm{CFU} / \mathrm{cm}^{2}$, respectively. Djordjevic et al. [41] observed a lower Enterobacteriaceae count in mixed pork and beef samples packaged in a modified atmosphere with higher concentration (50\%) of carbon dioxide. Malicki et al. [42] did not observe a significant antibacterial effect of $5 \%$ lysozyme monomer solution against coliform bacteria in chicken breast muscles. The bacterial growth was limited when lysozyme was combined with sodium acetate. Gramnegative bacteria are resistant to native lysozyme because their outer membrane prevents the enzymatic breakdown of the peptidoglycan layer [40]. A study on the shelf life of pork packaged in an air atmosphere showed that modified lysozyme was more effective against the Enterobacteriaceae bacteria than the lysozyme monomer [43].

The form of lysozyme and the composition of atmosphere had a statistically significant inhibitory effect on the count of yeasts and moulds during the storage of meat. The lowest count of yeasts and moulds was found in the meat samples with the modified lysozyme, regardless of the gas composition of the atmosphere (Table 2). The growth of yeasts and moulds in the samples with modified lysozyme packaged in the atmosphere containing $40 \%$ carbon dioxide (M2P) was observed after 28 days of storage, whereas in samples M1 and $\mathrm{M} 3$, which had lower $\mathrm{CO}_{2}$ content, yeasts and moulds were found after 19 days of storage. After 23 days of storage the count of yeasts and moulds in the samples with modified lysozyme, packaged in atmospheres M1 and M3 was respectively $1.12 \log \mathrm{CFU} / \mathrm{cm}^{2}$ and $1.88 \log \mathrm{CFU} / \mathrm{cm}^{2}$ lower than in the samples without the enzyme. At the end of storage, the lowest count of yeasts and moulds was found in sample M2P with the highest content of carbon dioxide in the package. After 28 days of storage there were no statistically significant differences between the count of yeasts and moulds in the meat samples with 
and without the lysozyme monomer. Malicki et al. [42] did not observe the antibacterial effect of the lysozyme monomer on yeasts and moulds in vacuum-packed chicken breast muscles stored under refrigeration.

Table 2. The effect of lysozyme and modified atmosphere on Enterobacteriaceae, moulds and yeasts and lactic acid bacteria in pork stored at $4{ }^{\circ} \mathrm{C} \pm 1{ }^{\circ} \mathrm{C}$.

\begin{tabular}{|c|c|c|c|c|}
\hline \multirow{3}{*}{ Treatment } & \multicolumn{4}{|c|}{ Population $\left[\log \mathrm{CFU} / \mathrm{cm}^{2} \pm \mathrm{SD}\right]$} \\
\hline & \multicolumn{4}{|c|}{ Storage Time [Day] } \\
\hline & 12 & 19 & 23 & 28 \\
\hline \multicolumn{5}{|c|}{ Enterobacteriaceae } \\
\hline M1C & - & $\mathrm{A}_{3.76} \pm 0.11_{\mathrm{bc}}$ & ${ }^{B} 4.45 \pm 0.08 \mathrm{e}$ & ${ }^{C} 5.56 \pm 0.17 \mathrm{e}$ \\
\hline M1M & - & A $3.44 \pm 0.09 \mathrm{a}$ & A $3.46 \pm 0.12_{c}$ & B $4.35 \pm 0.12 \mathrm{~cd}$ \\
\hline M1P & - & - & A $2.57 \pm 0.10 \mathrm{a}$ & ${ }^{\mathrm{B}} 3.82 \pm 0.04_{\mathrm{b}}^{\mathrm{u}}$ \\
\hline $\mathrm{M} 2 \mathrm{C}$ & - & - & A $2.75 \pm 0.11_{b}$ & ${ }^{B} 4.23 \pm 0.06_{c}$ \\
\hline $\mathrm{M} 2 \mathrm{M}$ & - & - & - & $2.67 \pm 0.05 \mathrm{a}$ \\
\hline M2P & - & - & - & - \\
\hline M3C & A $2.39 \pm 0.06$ & B $3.89 \pm 0.04_{c}$ & ${ }^{\mathrm{B}} 4.84 \pm 0.06_{\mathrm{f}}$ & $C_{5.68} \pm 0.03 \mathrm{e}$ \\
\hline M3M & - & A $3.58 \pm 0.29 \mathrm{ab}$ & B $3.96 \pm 0.03 \mathrm{~d}$ & $\mathrm{C}_{4.44 \pm 0.07 \mathrm{~d}}$ \\
\hline M3P & - & - & A $2.75 \pm 0.03 \mathrm{~b}$ & B $3.90 \pm 0.05 \mathrm{~b}$ \\
\hline \multicolumn{5}{|c|}{ Moulds and yeasts } \\
\hline M1C & - & $\mathrm{A} 1.57 \pm 0.03 \mathrm{a}$ & B $3.07 \pm 0.08 \mathrm{~d}$ & B $3.25 \pm 0.07 \mathrm{def}$ \\
\hline M1M & - & A $1.46 \pm 0.11 \mathrm{a}$ & B $3.06 \pm 0.10 \mathrm{~cd}$ & B $3.10 \pm 0.07 \mathrm{de}$ \\
\hline M1P & - & $\mathrm{A} 1.51 \pm 0.13 \mathrm{a}$ & B $1.95 \pm 0.04 \mathrm{a}$ & ${ }^{C} 2.42 \pm 0.10 \mathrm{ab}$ \\
\hline $\mathrm{M} 2 \mathrm{C}$ & - & - & A $2.67 \pm 0.02 \mathrm{~b}$ & B $3.16 \pm 0.12 \mathrm{de}$ \\
\hline $\mathrm{M} 2 \mathrm{M}$ & - & - & A $1.94 \pm 0.04 \mathrm{a}$ & B $2.99 \pm 0.08 \mathrm{~cd}$ \\
\hline $\mathrm{M} 2 \mathrm{P}$ & - & - & - & $2.17 \pm 0.07 \mathrm{a}$ \\
\hline $\mathrm{M} 3 \mathrm{C}$ & - & $\mathrm{A} 1.47 \pm 0.12 \mathrm{a}$ & B $3.42 \pm 0.09 \mathrm{e}$ & B $3.49 \pm 0.15_{f}$ \\
\hline M3M & - & $\mathrm{A} 1.64 \pm 0.35 \mathrm{a}$ & B $2.93 \pm 0.02 c$ & $C_{3.32} \pm 0.26 \mathrm{ef}$ \\
\hline M3P & - & A $1.32 \pm 0.05 \mathrm{a}$ & B $1.97 \pm 0.02 \mathrm{a}$ & $\mathrm{C}_{2.70 \pm 0.11 \mathrm{bc}}$ \\
\hline \multicolumn{5}{|c|}{ Lactic acid bacteria } \\
\hline M1C & $\mathrm{A}_{2.71 \pm 0.09 \mathrm{c}}$ & B $3.76 \pm 0.06_{d}$ & $C_{4.12 \pm 0.04} \mathrm{~cd}$ & D $4.64 \pm 0.05 \mathrm{~d}$ \\
\hline M1M & A $2.05 \pm 0.06 \mathrm{a}$ & B $3.34 \pm 0.12_{c}$ & $C_{4.11 \pm 0.11} \mathrm{~cd}$ & $C_{4.22 \pm 0.03}$ \\
\hline M1P & - & A $2.84 \pm 0.08_{b}$ & В $3.70 \pm 0.19 \mathrm{ab}$ & В $3.74 \pm 0.02_{b}$ \\
\hline $\mathrm{M} 2 \mathrm{C}$ & A $2.41 \pm 0.13_{b}$ & B $3.47 \pm 0.21_{c}$ & ${ }^{C} 4.34 \pm 0.13_{\mathrm{d}}^{\mathrm{ao}}$ & D $5.03 \pm 0.03 \mathrm{e}$ \\
\hline $\mathrm{M} 2 \mathrm{M}$ & A $2.17 \pm 0.17 \mathrm{a}$ & B $3.39 \pm 0.14_{c}$ & $C_{4.03 \pm 0.02} c_{c}$ & $C_{4.21 \pm 0.19}$ \\
\hline $\mathrm{M} 2 \mathrm{P}$ & - & A $2.47 \pm 0.02 \mathrm{a}$ & B $3.44 \pm 0.12 \mathrm{a}$ & В $3.45 \pm 0.06$ a \\
\hline M3C & A $2.22 \pm 0.03 \mathrm{a}$ & B $3.88 \pm 0.05_{c}$ & $C_{4.18} \pm 0.09 \mathrm{~cd}$ & $\mathrm{D} 4.52 \pm 0.06_{\mathrm{d}}^{\mathrm{a}}$ \\
\hline M3M & A $2.04 \pm 0.06 \mathrm{ab}$ & B $3.25 \pm 0.10 \mathrm{~d}$ & $\mathrm{C}_{3.95} \pm 002 \mathrm{bc}$ & $\mathrm{D}_{4.31} \pm 0.06_{\mathrm{c}}$ \\
\hline M3P & - & A $3.33 \pm 0.08_{c}$ & A $3.48 \pm 0.15 \mathrm{a}$ & B $3.71 \pm 0.08_{b}$ \\
\hline
\end{tabular}

All values are mean \pm SD of the replicates (8); (a-f) means with the same subscript are not different $(p>0.05)$-effect of treatments; (A-D) means with the same superscript are not different $(p>0.05)$-effect of time;-no growth in the sample; (M1-65:25:10 $\mathrm{O}_{2}: \mathrm{CO}_{2}: \mathrm{N}_{2}, \mathrm{M} 2-50: 40: 10 \mathrm{O}_{2}: \mathrm{CO}_{2}: \mathrm{N}_{2} \mathrm{M} 3-80: 20 \mathrm{O}_{2}: \mathrm{CO}_{2}, \mathrm{C}$-control, $\mathrm{M}$-monomer, $\mathrm{P}-$ modified lysozyme).

Lactic acid bacteria were found in the pork with modified lysozyme, packaged in all the atmospheres tested in the experiment, after 19 days of refrigerated storage (Table 2). Lactic acid bacteria are facultative anaerobes, which can grow in the presence of carbon dioxide [44]. The form of lysozyme had a statistically significant effect on the count of lactic acid bacteria in the meat during storage. Modified lysozyme was effective against the bacteria regardless of the composition of the atmosphere. After 19 days of meat storage the count of lactic acid bacteria in the samples with modified lysozyme packed in atmospheres M1, M2 and M3 was respectively $0.42 \log \mathrm{CFU} / \mathrm{cm}^{2}, 0.90 \mathrm{log} \mathrm{CFU} / \mathrm{cm}^{2}$ and $0.70 \log$ $\mathrm{CFU} / \mathrm{cm}^{2}$ lower than the LAB count in the samples without the lysozyme. At the end of meat storage, the LAB count ranged from 3.45 to $4.64 \log \mathrm{CFU} / \mathrm{cm}^{2}$. After 23 days of 
storage there were no statistically significant differences in the count of lactic acid bacteria between the meat samples without lysozyme.

\subsection{Meat Color}

The effect of the treatment on changes in the colour of meat stored under refrigeration is shown in Table 3. After 12 days of storage there was a statistically significant increase in the $\mathrm{L}^{*}$ value in all the samples. Depending on the sample type, it ranged from 52.32 to 55.00-57.18, as compared with the initial sample. The type of the sample did not have a statistically significant effect on the $L^{*}$ parameter value after 28 days of meat storage. The highest $\mathrm{L}^{*}$ parameter value was noted in sample M3C (Table 3A). Hu et al. [45] also observed increased lightness of pork during refrigerated storage. Viana et al. [36] observed a decrease in the lightness $\left(\mathrm{L}^{*}\right)$ of pork loin samples packaged in vacuum and different modified atmospheres: $100 \% \mathrm{CO}_{2} ; 99 \% \mathrm{CO}_{2}$ and $1 \% \mathrm{CO} ; 100 \% \mathrm{O}_{2} ; 100 \% \mathrm{CO}$, which were stored at $4{ }^{\circ} \mathrm{C}$. This result may have been caused by the high percentage of individual gases in the package.

Table 3. The colour parameters of pork with monomer and modified lysozyme packaged in modified atmosphere: (A) $\mathrm{L}^{*}$, $\mathrm{a}^{*}, \mathrm{~b}^{*}$ parameters; (B) $\mathrm{C}^{*}, \mathrm{~h}^{*}$ parameters.

(A)

\begin{tabular}{|c|c|c|c|c|c|c|}
\hline \multirow{3}{*}{ Treatment } & \multicolumn{6}{|c|}{ Color Parameters } \\
\hline & \multicolumn{6}{|c|}{ Storage Time [Day] } \\
\hline & 0 & 5 & 12 & 19 & 23 & 28 \\
\hline \multicolumn{7}{|c|}{$\mathrm{L}^{*}$} \\
\hline $\begin{array}{l}\text { M1C } \\
\text { M1M } \\
\text { M1P } \\
\text { M2C } \\
\text { M2M } \\
\text { M2P } \\
\text { M3C } \\
\text { M3M } \\
\text { M3P }\end{array}$ & $\begin{array}{l}\text { A } 52.32 \pm 1.15 \mathrm{a} \\
\text { A } 52.32 \pm 1.15 \mathrm{a} \\
\text { A } 52.32 \pm 1.15 \mathrm{a} \\
\text { A } 5.32 \pm 1.15 \mathrm{a} \\
\text { A } 52.32 \pm 1.15 \mathrm{a} \\
\text { A } 52.32 \pm 1.15 \mathrm{a} \\
\text { A } 52.32 \pm 1.15 \mathrm{a} \\
\text { AB } 52.32 \pm 1.15 \mathrm{a} \\
\text { A } 52.32 \pm 1.15 \mathrm{a}\end{array}$ & $\begin{array}{c}\mathrm{AB} 53.68 \pm 0.22 \mathrm{a} \\
\mathrm{A} 53.22 \pm 1.58 \mathrm{a} \\
\mathrm{AB} 54.00 \pm 1.72 \mathrm{a} \\
\mathrm{A} 52.16 \pm 1.21 \mathrm{a} \\
\mathrm{A} 51.48 \pm 0.67 \mathrm{a} \\
\mathrm{A} 51.98 \pm 1.16 \mathrm{a} \\
\mathrm{AB} 53.78 \pm 1.65 \mathrm{a} \\
\mathrm{A} 51.70 \pm 0.70 \mathrm{a} \\
\mathrm{AB} 54.52 \pm 2.79 \mathrm{a}\end{array}$ & $\begin{array}{c}\text { BC } 55.66 \pm 1.16 \mathrm{a} \\
\text { B } 55.96 \pm 1.15 \mathrm{a} \\
\text { B } 56.50 \pm 1.35 \mathrm{a} \\
\text { B } 55.24 \pm 1.29 \mathrm{a} \\
\text { BC } 55.94 \pm 1.31 \mathrm{a} \\
\text { B } 56.10 \pm 1.72 \mathrm{a} \\
\text { C } 57.18 \pm 1.04 \mathrm{a} \\
\text { C } 56.70 \pm 1.56 \mathrm{a} \\
\text { ABC } 55.00 \pm 1.83 \mathrm{a}\end{array}$ & $\begin{array}{c}\text { ABC } 54.84 \pm 2.45 \mathrm{ab} \\
\text { B } 57.22 \pm 0.33 \mathrm{bc} \\
\text { AB } 55.00 \pm 0.70_{\mathrm{ab}} \\
\text { AB } 54.12 \pm 1.38 \mathrm{a} \\
\text { D } 61.16 \pm 1.63 \mathrm{~d} \\
\text { B } 56.34 \pm 1.51 \mathrm{abc} \\
\text { BC } 55.54 \pm 0.73 \mathrm{abc} \\
\text { ABC } 54.56 \pm 1.68 \mathrm{ab} \\
\text { C } 58.34 \pm 0.67 \mathrm{~cd} \\
\end{array}$ & $\begin{array}{c}\text { BC } 55.58 \pm 0.80 \mathrm{ab} \\
\text { B } 56.52 \pm 1.01_{\mathrm{b}} \\
\text { B } 56.60 \pm 2.64_{\mathrm{b}} \\
\text { B } 56.26 \pm 1.26 \mathrm{ab} \\
\text { AB } 53.32 \pm 1.27 \mathrm{a} \\
\text { B } 56.48 \pm 2.83_{\mathrm{b}} \\
\text { BC } 56.30 \pm 0.32_{\mathrm{ab}} \\
\text { ABC } 54.88 \pm 0.43_{\mathrm{ab}} \\
\text { BC } 57.16 \pm 0.27 \mathrm{~b} \\
\end{array}$ & $\begin{array}{c}\text { C } 56.58 \pm 0.90 \mathrm{ab} \\
\text { B } 55.98 \pm 0.90 \mathrm{ab} \\
\mathrm{AB} 55.08 \pm 1.87 \mathrm{ab} \\
\mathrm{AB} 54.12 \pm 0.79 \mathrm{a} \\
\mathrm{C}^{5} 56.04 \pm 0.99 \mathrm{ab} \\
\text { B } 56.86 \pm 0.72 \mathrm{ab} \\
\text { C } 57.94 \pm 2.19 \mathrm{~b} \\
\mathrm{ABC} 55.16 \pm 2.48 \mathrm{ab} \\
\mathrm{ABC} 55.90 \pm 2.80 \mathrm{ab}\end{array}$ \\
\hline \multicolumn{7}{|c|}{$a^{*}$} \\
\hline $\begin{array}{l}\text { M1C } \\
\text { M1M } \\
\text { M1P } \\
\text { M2C } \\
\text { M2M } \\
\text { M2P } \\
\text { M3C } \\
\text { M3M } \\
\text { M3P }\end{array}$ & $\begin{array}{l}\mathrm{BC} 6.12 \pm 1.22 \mathrm{a} \\
\mathrm{AB} 6.12 \pm 1.22 \mathrm{a} \\
\mathrm{AB} 6.12 \pm 1.22 \mathrm{a} \\
\mathrm{A} 6.12 \pm 1.22 \mathrm{a} \\
\mathrm{AB} 6.12 \pm 1.22 \mathrm{a} \\
\mathrm{AB} 6.12 \pm 1.22 \mathrm{a} \\
\mathrm{A} 6.12 \pm 1.22 \mathrm{a} \\
\mathrm{AB} 6.12 \pm 1.22 \mathrm{a} \\
\mathrm{AB} 6.12 \pm 1.22 \mathrm{a}\end{array}$ & $\begin{array}{l}\text { C } 6.62 \pm 0.38 \mathrm{a} \\
\text { B } 7.56 \pm 0.56 \mathrm{abc} \\
{ }^{\mathrm{B}} 7.00 \pm 0.51 \mathrm{ab} \\
{ }^{\text {A }} 8.68 \pm 0.52 \mathrm{~cd} \\
{ }^{C} 9.82 \pm 0.45 \mathrm{~d} \\
\text { B } 7.32 \pm 0.90 \mathrm{ab} \\
\text { B } 8.06 \pm 0.84 \mathrm{bc} \\
\text { B } 6.84 \pm 0.33 \mathrm{ab} \\
{ }^{\text {B }} 7.50 \pm 0.92 \mathrm{abc}\end{array}$ & $\begin{array}{c}\text { BC } 6.14 \pm 0.65 \mathrm{ab} \\
\mathrm{AB} 6.26 \pm 0.82 \mathrm{ab} \\
\text { A } 5.42 \pm 0.33_{\mathrm{ab}} \\
\mathrm{A}^{\mathrm{A}} 6.60 \pm 0.46_{\mathrm{b}} \\
\mathrm{AB}^{\mathrm{B}} 6.32 \pm 0.63 \mathrm{ab} \\
\text { A } 5.58 \pm 0.37 \mathrm{ab} \\
\text { A } 5.30 \pm 0.79 \mathrm{a} \\
\mathrm{AB} 6.32 \pm 0.86 \mathrm{ab} \\
\text { A } 5.76 \pm 0.11_{\mathrm{ab}}\end{array}$ & $\begin{array}{c}\mathrm{ABC} 5.52 \pm 1.10 \mathrm{ab} \\
\mathrm{A} 5.20 \pm 0.86 \mathrm{a} \\
\mathrm{AB} 6.20 \pm 0.55 \mathrm{ab} \\
{ }^{\mathrm{A}} 6.04 \pm 0.47 \mathrm{ab} \\
{ }^{\mathrm{B}} 6.82 \pm 0.41_{\mathrm{b}} \\
\mathrm{AB}^{\mathrm{AB}} 6.04 \pm 0.36_{\mathrm{ab}} \\
\mathrm{A} 5.80 \pm 0.21 \mathrm{ab} \\
\mathrm{AB} 5.80 \pm 0.43_{\mathrm{ab}} \\
\text { A } 5.66 \pm 0.65 \mathrm{ab}\end{array}$ & $\begin{array}{c}\text { AB } 5.08 \pm 0.40 \mathrm{a} \\
\text { A } 5.22 \pm 0.44 \mathrm{ab} \\
\text { A } 5.06 \pm 0.48 \mathrm{a} \\
\text { B } 5.60 \pm 0.76 \mathrm{ab} \\
{ }^{\mathrm{B}} 6.76 \pm 0.42 \mathrm{c} \\
\mathrm{AB}^{\mathrm{A}} 6.14 \pm 0.47 \mathrm{bc} \\
\text { A } 5.74 \pm 0.36 \mathrm{ab} \\
\text { AB } 5.58 \pm 0.15_{\mathrm{ab}} \\
\text { A } 5.22 \pm 0.29 \mathrm{ab}\end{array}$ & $\begin{array}{c}\text { A } 4.42 \pm 0.54 \mathrm{a} \\
\text { A } 5.48 \pm 0.33_{\mathrm{bc}} \\
\mathrm{AB} 6.22 \pm 0.57 \mathrm{c} \\
\text { A } 6.10 \pm 0.47_{\mathrm{c}} \\
\text { A } 5.42 \pm 0.31_{\mathrm{bc}} \\
\text { A } 5.52 \pm 0.28_{\mathrm{bc}} \\
\text { A } 5.88 \pm 0.06_{\mathrm{f}} \\
\text { AB } 5.08 \pm 0.03_{\mathrm{d}} \\
\text { A } 5.38 \pm 0.09_{\mathrm{c}}\end{array}$ \\
\hline \multicolumn{7}{|c|}{$\mathrm{b}^{*}$} \\
\hline $\begin{array}{l}\text { M1C } \\
\text { M1M } \\
\text { M1P } \\
\text { M2C } \\
\text { M2M } \\
\text { M2P } \\
\text { M3C } \\
\text { M3M } \\
\text { M3P }\end{array}$ & $\begin{array}{l}\text { A } 2.82 \pm 1.12 \mathrm{a} \\
\text { A } 2.82 \pm 1.12 \mathrm{a} \\
\text { A } 2.82 \pm 1.12 \mathrm{a} \\
\text { A } 2.82 \pm 1.12 \mathrm{a} \\
\text { A } 2.82 \pm 1.12 \mathrm{a} \\
\text { A } 2.82 \pm 1.12 \mathrm{a} \\
\text { A } 2.82 \pm 1.12 \mathrm{a} \\
\text { A } 2.82 \pm 1.12 \mathrm{a} \\
\text { A } 2.82 \pm 1.12 \mathrm{a}\end{array}$ & 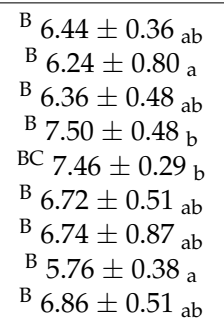 & 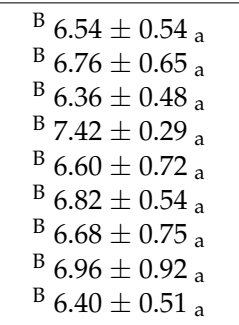 & 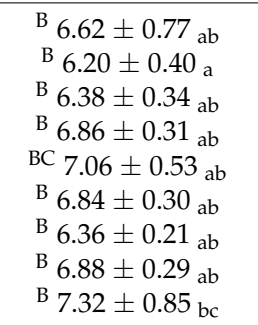 & $\begin{array}{l}\text { В } 6.32 \pm 0.26 \mathrm{a} \\
\text { В } 6.56 \pm 0.24 \mathrm{a} \\
\text { В } 6.70 \pm 0.52 \mathrm{a} \\
\text { В } 6.50 \pm 0.84 \mathrm{a} \\
\text { В } 6.24 \pm 0.65 \mathrm{a}_{\mathrm{a}} \\
\text { В } 7.04 \pm 0.44 \mathrm{a} \\
\text { В } 6.80 \pm 0.43 \mathrm{a} \\
\text { В } 6.96 \pm 0.25 \mathrm{a} \\
\text { В } 6.88 \pm 0.25 \mathrm{a}\end{array}$ & $\begin{array}{l}\text { В } 6.78 \pm 0.62 \mathrm{a} \\
\text { В } 6.96 \pm 0.53 \mathrm{a} \\
\text { В } 6.62 \pm 0.76 \mathrm{a} \\
\text { В } 7.22 \pm 0.25 \mathrm{a} \\
\text { В } 6.08 \pm 0.77 \mathrm{a}_{\mathrm{a}} \\
\text { В } 6.98 \pm 0.38 \mathrm{a}_{\mathrm{a}} \\
\text { В } 7.36 \pm 0.58 \mathrm{a} \\
{ }^{\text {В }} 6.82 \pm 0.93 \mathrm{a} \\
{ }^{\text {В }} 6.73 \pm 0.22 \mathrm{a}\end{array}$ \\
\hline
\end{tabular}

All values are mean $\pm \mathrm{SD}$ of the replicates (6); (a-f) means with the same subscript are not different ( $p>0.05)$-effect of treatments; (A-D) means with the same superscript are not different $(p>0.05)$-effect of time; $\left(\mathrm{M} 1-65: 25: 10 \mathrm{O}_{2}: \mathrm{CO}_{2}: \mathrm{N}_{2}, \mathrm{M} 2-50: 40: 10 \mathrm{O}_{2}: \mathrm{CO}_{2}: \mathrm{N}_{2} \mathrm{M}_{-}-80: 20\right.$ $\mathrm{O}_{2}: \mathrm{CO}_{2}, \mathrm{C}-$ control, $\mathrm{M}-$ monomer, $\mathrm{P}$-modified lysozyme). 
Table 3. Cont.

(B)

\begin{tabular}{|c|c|c|c|c|c|c|}
\hline \multirow{3}{*}{ Treatment } & \multicolumn{6}{|c|}{ Color Parameters } \\
\hline & \multicolumn{6}{|c|}{ Storage Time [Day] } \\
\hline & 0 & 5 & 12 & 19 & 23 & 28 \\
\hline \multicolumn{7}{|c|}{$C^{*}$} \\
\hline $\begin{array}{l}\text { M1C } \\
\text { M1M } \\
\text { M1P } \\
\text { M2C } \\
\text { M2M } \\
\text { M2P } \\
\text { M3C } \\
\text { M3M } \\
\text { M3P }\end{array}$ & $\begin{array}{l}\text { A } 6.79 \pm 1.33 \mathrm{a} \\
\text { A } 6.79 \pm 1.33 \mathrm{a} \\
\text { A } 6.79 \pm 1.33 \mathrm{a} \\
\text { A } 6.79 \pm 1.33 \mathrm{a} \\
\text { A } 6.79 \pm 1.33 \mathrm{a} \\
\text { A } 6.79 \pm 1.33 \mathrm{a} \\
\text { A } 6.79 \pm 1.33 \mathrm{a} \\
\text { A } 6.79 \pm 1.33 \mathrm{a} \\
\text { A } 6.79 \pm 1.33 \mathrm{a}\end{array}$ & $\begin{array}{l}\text { В } 9.24 \pm 0.31 \mathrm{ab} \\
\text { В } 9.81 \pm 0.92 \mathrm{ab} \\
\text { В } 9.46 \pm 0.56 \mathrm{ab} \\
\text { C } 11.47 \pm 0.67 \mathrm{a} \\
\text { D } 12.33 \pm 0.47 \mathrm{c} \\
\text { В } 9.95 \pm 0.92 \mathrm{abc} \\
\text { C } 10.51 \pm 1.19 \mathrm{bc} \\
\text { В } 8.95 \pm 0.33_{\mathrm{a}} \\
\text { C } 10.17 \pm 0.80 \mathrm{abc}\end{array}$ & $\begin{array}{c}\text { B } 8.99 \pm 0.61 \mathrm{a} \\
\text { В } 9.22 \pm 0.94 \mathrm{a} \\
\text { B } 8.36 \pm 0.52 \mathrm{a} \\
\text { BC } 9.93 \pm 0.50 \mathrm{a} \\
\mathrm{BC} 9.14 \pm 0.94 \mathrm{a} \\
\text { B } 8.81 \pm 0.64 \mathrm{a} \\
\text { AB } 8.53 \pm 1.05 \mathrm{a} \\
\text { B } 9.40 \pm 1.25 \mathrm{a} \\
\text { BC } 8.61 \pm 0.44 \mathrm{a}\end{array}$ & $\begin{array}{c}\text { В } 8.64 \pm 1.16_{\mathrm{a}} \\
\text { AB } 8.10 \pm 0.85 \mathrm{a} \\
\text { В } 8.91 \pm 0.46_{\mathrm{a}} \\
\text { В } 9.15 \pm 0.44 \mathrm{a} \\
\text { C } 10.57 \pm 0.48_{\mathrm{b}} \\
\text { В } 9.13 \pm 0.28 \mathrm{a} \\
\text { В } 8.61 \pm 0.20 \mathrm{a} \\
\text { В } 9.00 \pm 0.39 \mathrm{ab} \\
\text { BC } 9.25 \pm 1.07 \mathrm{ab}\end{array}$ & $\begin{array}{c}\text { AB } 8.12 \pm 0.25 \mathrm{a} \\
\text { AB } 8.39 \pm 0.39 \mathrm{ab} \\
\text { B } 8.41 \pm 0.40_{\mathrm{ab}} \\
\text { B } 8.58 \pm 1.10_{\mathrm{ab}} \\
\mathrm{BC} 9.21 \pm 0.64_{\mathrm{b}} \\
\text { B } 9.34 \pm 0.46_{\mathrm{b}} \\
\text { BC } 8.91 \pm 0.28 \mathrm{ab} \\
\text { B } 8.92 \pm 0.20 \mathrm{ab} \\
\text { BC } 8.64 \pm 0.30_{\mathrm{ab}}\end{array}$ & $\begin{array}{l}\mathrm{AB} 8.11 \pm 0.64 \mathrm{a} \\
\mathrm{B} 8.86 \pm 0.61 \mathrm{a} \\
\mathrm{B} 9.09 \pm 0.81 \mathrm{a} \\
\mathrm{B} 9.46 \pm 0.37 \mathrm{a} \\
\mathrm{AB} 8.16 \pm 0.63 \mathrm{a} \\
\text { B } 8.90 \pm 0.37 \mathrm{a} \\
\mathrm{BC} 9.42 \pm 0.79 \mathrm{a} \\
\mathrm{AB} 8.51 \pm 1.06 \mathrm{a} \\
\mathrm{AB} 8.05 \pm 0.65 \mathrm{a}\end{array}$ \\
\hline \multicolumn{7}{|c|}{$h^{*}$} \\
\hline $\begin{array}{l}\text { M1C } \\
\text { M1M } \\
\text { M1P } \\
\text { M2C } \\
\text { M2M } \\
\text { M2P } \\
\text { M3C } \\
\text { M3M } \\
\text { M3P }\end{array}$ & $\begin{array}{l}\text { A } 24.42 \pm 8.57 \mathrm{ab} \\
\text { A } 24.42 \pm 8.57 \mathrm{~b} \\
\text { A } 24.42 \pm 8.57 \mathrm{~b} \\
\text { A } 24.42 \pm 8.57 \mathrm{a} \\
\text { A } 24,42 \pm 8.57 \mathrm{a} \\
\text { A } 24.42 \pm 8.57 \mathrm{a} \\
\text { A } 24.42 \pm 8.57 \mathrm{a} \\
\text { A } 24.42 \pm 8.57 \mathrm{a} \\
\text { A } 24.42 \pm 8.57 \mathrm{a}\end{array}$ & $\begin{array}{l}\text { В } 44.22 \pm 2.62 \mathrm{a} \\
\text { В } 39.42 \pm 2.11 \mathrm{abc} \\
\text { В } 42.27 \pm 2.44 \mathrm{ab} \\
\text { В } 40.83 \pm 1.09 \mathrm{ab} \\
\text { В } 37.24 \pm 1.18_{\mathrm{b}} \\
\text { В } 42.69 \pm 2.76_{\mathrm{b}} \\
\text { В } 39.85 \pm 1.28 \mathrm{ab} \\
\text { В } 40.10 \pm 2.41_{\mathrm{ab}} \\
\text { В } 42.66 \pm 3.83_{\mathrm{b}}\end{array}$ & 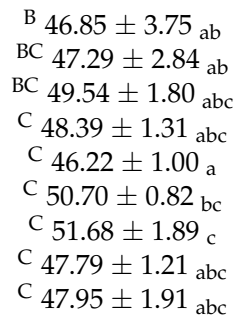 & $\begin{array}{c}\text { BC } 50.45 \pm 4.49 \mathrm{ab} \\
\text { C } 50.25 \pm 2.95 \mathrm{ab} \\
\text { BC } 45.88 \pm 2.97 \mathrm{a} \\
\text { C }_{48.68 \pm 2.20 a b} \\
\text { C } 49.75 \pm 2.49 \mathrm{ab} \\
\text { BC } 48.57 \pm 2.34 \mathrm{ab} \\
\text { C } 47.64 \pm 1.48 \mathrm{ab} \\
\text { C } 49.91 \pm 2.24 \mathrm{ab} \\
\text { C } 52.29 \pm 0.21 \mathrm{~b}\end{array}$ & $\begin{array}{l}\text { BC } 51.24 \pm 2.86_{b} \\
\text { C } 51.55 \pm 2.16_{b} \\
\text { C } 53.92 \pm 3.95_{b} \\
\text { C } 49.28 \pm 1.84_{a} \\
\text { BC } 42.64 \pm 2.70_{a} \\
\text { BC } 48.92 \pm 2.75_{a} \\
\text { C } 49.82 \pm 3.14_{b} \\
\text { C } 51.28 \pm 1.33_{b} \\
\text { C } 52.83 \pm 1.55_{b}\end{array}$ & $\begin{array}{c}\text { D } 56.88 \pm 3.74 \mathrm{~d} \\
\mathrm{C}_{51.77 \pm 1.07} \mathrm{abcd} \\
\text { BC } 46.71 \pm 3.29 \mathrm{a} \\
\mathrm{C}_{49.86 \pm 2.35 \mathrm{ab}} \\
\mathrm{C}_{48.12} \pm 3.88 \mathrm{abc} \\
\mathrm{A}_{51.66 \pm 1.86} \mathrm{abc} \\
\text { A } 51.41 \pm 1.40 \mathrm{abc} \\
\mathrm{AB} 53.25 \pm 1.23 \mathrm{bcd} \\
\text { A } 53.32 \pm 1.40 \mathrm{~cd}\end{array}$ \\
\hline
\end{tabular}

All values are mean \pm SD of the replicates (6); (a-d) means with the same subscript are not different $(p>0.05)$-effect of treatments; (A-D) means with the same superscript are not different $(p>0.05)$-effect of time; (M1-65:25:10 $\mathrm{O}_{2}: \mathrm{CO}_{2}: \mathrm{N}_{2}, \mathrm{M} 2-50: 40: 10 \mathrm{O}_{2}: \mathrm{CO}_{2}: \mathrm{N}_{2} \mathrm{M}_{3}-80: 20$ $\mathrm{O}_{2}: \mathrm{CO}_{2}, \mathrm{C}$-control, $\mathrm{M}$-monomer, $\mathrm{P}$-modified lysozyme).

The addition of lysozyme did not cause a statistically significant reduction in the redness $\left(a^{*}\right)$ of raw pork, as compared with the control sample (Table $\left.3 \mathrm{~A}\right)$. During the storage of meat, in most cases there were no statistically significant differences in the $a^{*}$ parameter value between the samples. During the first five days of storage the value increased in all the samples, regardless of the gas atmosphere and the addition of lysozyme. The result of our experiment is consistent with the results obtained by other authors, who observed an initial increase in the $\mathrm{a}^{*}$ parameter value in raw meat, which was followed by a decrease due to the formation of metmyoglobin [46,47]. After 28 days of meat storage the lowest $\mathrm{a}^{*}$ parameter value was noted in sample M1C, without lysozyme, packed in an atmosphere containing $65 \%$ of oxygen. Apart from this sample, there were no statistically significant differences in the $\mathrm{a}^{*}$ value between the meat samples in the initial and final period of storage (Table 3A).

After five days of storage there was a statistically significant increase in the $b^{*}$ value in all the samples regardless of the composition of atmosphere and the form of lysozyme. These values did not change throughout the storage period. During the refrigerated storage of meat there were no significant differences in the yellowness $\left(b^{*}\right)$ parameter values in the control samples, monomer and the samples modified by the lysozyme, regardless of the composition of the atmosphere (Table 3A).

During the first days of storage the $\mathrm{C}^{*}$ value increased in all samples (Table 3B). There were no statistically significant differences in the $C^{*}$ value between the meat samples in the initial ( 5 days) and final period of storage ( 28 days). After 23 days of meat storage, the highest $\mathrm{C}^{*}$ parameter value and the lowest $\mathrm{h}^{*}$ parameter value were noted in the samples with monomer and modified lysozyme, packed in an atmosphere containing 50\% $\mathrm{O}_{2}, 40 \%$ $\mathrm{CO}_{2}, 10 \% \mathrm{~N}_{2}(\mathrm{M} 2 \mathrm{M}, \mathrm{M} 2 \mathrm{P})$. Higher $\mathrm{C}^{*}$ values indicate greater red color intensity, whereas higher $\mathrm{h}^{*}$ values indicate a less red and more discolored sample.

The colour and bacterial count are the most important criteria of meat freshness during storage. The shelf life of pork largely depends on its colour, which often changes for the worse before microbial spoilage. The applied forms of lysozyme did not have negative 
influence on the meat colour parameters. Also, the authors in previous studies did not observe any significant effect of the monomer and modified lysozyme on the values of the $L^{*}$ and $a^{*}$ parameters of minced pork packed in an air atmosphere [35]. Nattress and Baker [48] did not observe a significant effect of lysozyme, nisin or their mixtures on the values of the $\mathrm{L}^{*}$ and $\mathrm{a}^{*}$ parameters in fresh pork. As results from the data in the reference publications, oxygen is essential to maintain the desirable colour of fresh meat [49]. In the study by Lukic et al. [37] pork chops packed in an atmosphere containing $70 \%$ of $\mathrm{O}_{2}$ and $30 \%$ of $\mathrm{CO}_{2}$ had the highest ratings for colour.

\subsection{Aroma Changes}

In the initial period all the meat samples, both those with lysozyme and those without the enzyme, had a desirable, intrinsic aroma of fresh meat (Table 4). The unfavourable changes in the aroma appeared first in the control sample packed in atmosphere M3 with the highest oxygen content. In most of the samples there were type-dependent statistically significant changes in the smell after 19 days of meat storage. During the storage the samples with the modified lysozyme received the highest ratings for the aroma, regardless of the type of atmosphere used. After 19 and 23 days of meat storage there were statistically significant differences between the sample with modified lysozyme, packed in atmosphere M2 with the highest content of carbon dioxide, and the samples with the enzyme, packed in atmospheres M1 and M3. In the final period of storage this sample was rated the highest for its aroma. At the same time, it had the lowest count of bacteria. The best sensory results were noted for the samples with modified lysozyme packaged in an atmosphere with $40 \%$ $\mathrm{CO}_{2}$. After 23 days of storage its odour was rated 4.1. The panelists rated the odour of the other samples as unacceptable. In that period the highest total bacterial counts (5.49-5.67 $\log \mathrm{CFU} / \mathrm{cm}^{2}$ ) were noted in the samples without lysozyme, packed in an atmosphere with lower $\mathrm{CO}_{2}$ content. Lukic et al. [37] found that twelve days after storage, the pork chops in MAP3 $\left(80 \% \mathrm{O}_{2}: 20 \% \mathrm{CO}_{2}\right)$ were declared as unacceptable due to colour changes.

Table 4. Effect of lysozyme and modified atmosphere on aroma of pork meat stored at $4{ }^{\circ} \mathrm{C} \pm 1{ }^{\circ} \mathrm{C}$.

\begin{tabular}{|c|c|c|c|c|c|c|}
\hline \multirow{3}{*}{ Treatment } & \multicolumn{6}{|c|}{ Aroma } \\
\hline & \multicolumn{6}{|c|}{ Storage Time [Day] } \\
\hline & 0 & 5 & 12 & 19 & 23 & 28 \\
\hline M1C & A $5.0 \pm 0.0 \mathrm{a}$ & A $5.0 \pm 0.0 \mathrm{a}$ & ${ }^{\mathrm{B}} 4.2 \pm 0.2_{c}$ & $\mathrm{C}_{3.8 \pm 0.1_{\mathrm{c}}}$ & D $3.4 \pm 0.1_{b}$ & ${ }^{\mathrm{E}} 1.9 \pm 0.2_{\mathrm{d}}$ \\
\hline M1M & A $5.0 \pm 0.0 \mathrm{a}$ & A $5.0 \pm 0.0 \mathrm{a}$ & A $5.0 \pm 0.0 \mathrm{a}$ & ${ }^{B} 4.0 \pm 0.1_{b}$ & $C_{3.4 \pm 0.1_{b}}$ & D $2.0 \pm 0.1_{\mathrm{d}}$ \\
\hline M1P & A $5.0 \pm 0.0 \mathrm{a}$ & A $5.0 \pm 0.0 \mathrm{a}$ & A $5.0 \pm 0.0 \mathrm{a}$ & ${ }^{\mathrm{B}} 4.0 \pm 0.1_{\mathrm{b}}$ & $C_{3.6 \pm 0.3}$ & D $2.5 \pm 0.3_{c}$ \\
\hline M2C & A $5.0 \pm 0.0 \mathrm{a}$ & A $5.0 \pm 0.0 \mathrm{a}$ & ${ }^{\text {B }} 4.5 \pm 0.1_{b}$ & $\mathrm{C}_{4.0} \pm 0.1_{\mathrm{b}}$ & D $3.5 \pm 0.3_{b}$ & ${ }^{\mathrm{E}} 2.5 \pm 0.3 \mathrm{bc}$ \\
\hline M2M & A $5.0 \pm 0.0 \mathrm{a}$ & A $5.0 \pm 0.0 \mathrm{a}$ & A $5.0 \pm 0.0 \mathrm{a}$ & ${ }^{\mathrm{B}} 4.0 \pm 0.1_{\mathrm{b}}$ & $C_{3.6 \pm 0.3}$ & D $2.8 \pm 0.4 \mathrm{ab}$ \\
\hline $\mathrm{M} 2 \mathrm{P}$ & A $5.0 \pm 0.0 \mathrm{a}$ & A $5.0 \pm 0.0 \mathrm{a}$ & A $5.0 \pm 0.0 \mathrm{a}$ & В $4.7 \pm 0.4$ a & $\mathrm{C}_{4.1} \pm 0.1_{\mathrm{a}}$ & D $3.0 \pm 0.1 \mathrm{a}$ \\
\hline M3C & A $5.0 \pm 0.0 \mathrm{a}$ & ${ }^{\mathrm{B}} 4.6 \pm 0.4_{\mathrm{b}}$ & $\mathrm{C}_{4.0} \pm 0.1_{\mathrm{d}}$ & D $3.6 \pm 0.3_{c}$ & ${ }^{\mathrm{E}} 3.0 \pm 0.3_{c}$ & $\mathrm{~F} 1.8 \pm 0.1_{\mathrm{d}}$ \\
\hline M3M & A $5.0 \pm 0.0 \mathrm{a}$ & A $5.0 \pm 0.0 \mathrm{a}$ & ${ }^{\mathrm{B}} 4.4 \pm 0.0_{\mathrm{b}}$ & $\mathrm{C}_{3.9 \pm 0.1_{\mathrm{b}}}$ & D $3.1 \pm 0.1_{c}$ & ${ }^{\mathrm{E}} 1.9 \pm 0.1_{\mathrm{d}}$ \\
\hline M3P & ${ }^{A} 5.0 \pm 0.0 \mathrm{a}$ & ${ }^{\mathrm{A}} 5.0 \pm 0.0 \mathrm{a}$ & ${ }^{\text {B }} 4.5 \pm 0.1_{b}$ & $C 4.1 \pm 0.1_{b}$ & D $3.5 \pm 0.3_{b}$ & ${ }^{\mathrm{E}} 2.1 \pm 0.1_{\mathrm{d}}$ \\
\hline
\end{tabular}

All values are mean \pm SD of the replicates (16); (a-d) means with the same subscript are not different $(p>0.05)-$ effect of treatment; $(\mathrm{A}-\mathrm{F})$ means with the same superscript are not different $(p>0.05)$-effect of time; (M1 -65:25:10 $\mathrm{O}_{2}: \mathrm{CO}_{2}: \mathrm{N}_{2}, \mathrm{M} 2-50: 40: 10 \mathrm{O}_{2}: \mathrm{CO}_{2}: \mathrm{N}_{2}, \mathrm{M} 3-80: 20 \mathrm{O}_{2}: \mathrm{CO}_{2}, \mathrm{C}$-control, M-monomer, P-modified lysozyme).

Cegielska-Radziejewska and Szablewski [35] researched the use of lysozyme to fix ground pork and noted that the samples with the modified lysozyme were rated the highest for aroma. The sensory evaluation in the study by Nattress et al. [48] revealed no difference between the vacuum-packed pork loins treated with lysozyme and nisin and the untreated samples. However, off-odours were more prevalent in the aerobically displayed chops treated with antimicrobials than in the untreated samples.

\subsection{Value of $p H$}

The initial $\mathrm{pH}$ of the meat was 5.33. In the initial period of storage the $\mathrm{pH}$ value dropped by 0.10 in all the samples. In our study the $\mathrm{pH}$ of the pork samples changed insignificantly during the 28 days of storage. After 28 days the lowest $\mathrm{pH}$ (5.30) was noted 
in sample M2P, but it was only 0.1 and 0.15 lower than the $\mathrm{pH}$ of the control samples M2K and M1K. Similarly, Viana et al. [36] did not observe significant variation in the $\mathrm{pH}$ of MAP-treated fresh pork loin samples during the storage period. Nattress et al. [48] noted that the $\mathrm{pH}$ of vacuum-packed pork loins treated with lysozyme and nisin was only 0.1 higher than the $\mathrm{pH}$ of untreated loins.

So far, most studies on the antimicrobial effect of monomer and other forms of lysozyme have been conducted under model conditions [11,12]. The lysozyme monomer was effective against bacteria in meat and its products when the enzyme was used in combination with EDTA, sodium lactate, sodium acetate or nisin $[1,39,42,48,50,51]$. The treatment of chilled buffalo meat with $0.5 \%$ lysozyme and $2 \%$ EDTA reduced the total mesophilic viable count, total psychrotrophic viable count, and the counts of lactic acid bacteria and Pseudomonas spp. The combination of lysozyme with nisin extended the shelf life of naturally contaminated fresh pork [38]. Rollini et al. [52] observed that lysozymelactoferrin-coated PET reduced the count of $\mathrm{H}_{2} \mathrm{~S}$-producing bacteria in fresh salmon at $5{ }^{\circ} \mathrm{C}$. Costa et al. [6] found that the antimicrobial compounds in the filling of burrata cheese (lysozyme and $\mathrm{N}_{2}$-EDTA), coatings with silver nanoparticles and packaging under 65:35 $\mathrm{CO}_{2}: \mathrm{N}_{2}$ were effective condition to quarantee product preservation. Under these conditions, the shelf life of burrata cheese was extended from three days (the control sample) to ten days. There have been few studies on the possibility to use the properties of the modified enzyme to extend the shelf life of food. Cegielska-Radziejewska et al. [53] found that a lysozyme dimer solution applied to the surface of chicken breast muscles extended the shelf life of the product. The authors' earlier study showed that modified lysozyme was more effective than monomer lysozyme against bacteria in ground pork, especially Pseudomonas spp. and Enterobacteriaceae. The antimicrobial activity of modified lysozyme in heated meat was more effective. After $144 \mathrm{~h}$ of meat storage the difference in the count of Enterobacteriaceae between the control sample and the one with the modified lysozyme was $2.4 \log$ CFU/g. The lowest counts of Pseudomonas spp. were found in the samples with the modified lysozyme. During the meat storage the lowest count of lactic acid bacteria was found in the sample with the modified lysozyme [35].

Two principal components explaining $84.77 \%$ of the total variability $(\mathrm{PC} 1-62.06 \%$ of variability; PC2-22.71\% of variability) were identified in the correlation matrix. Figure 1 shows their correlations with the input variables.
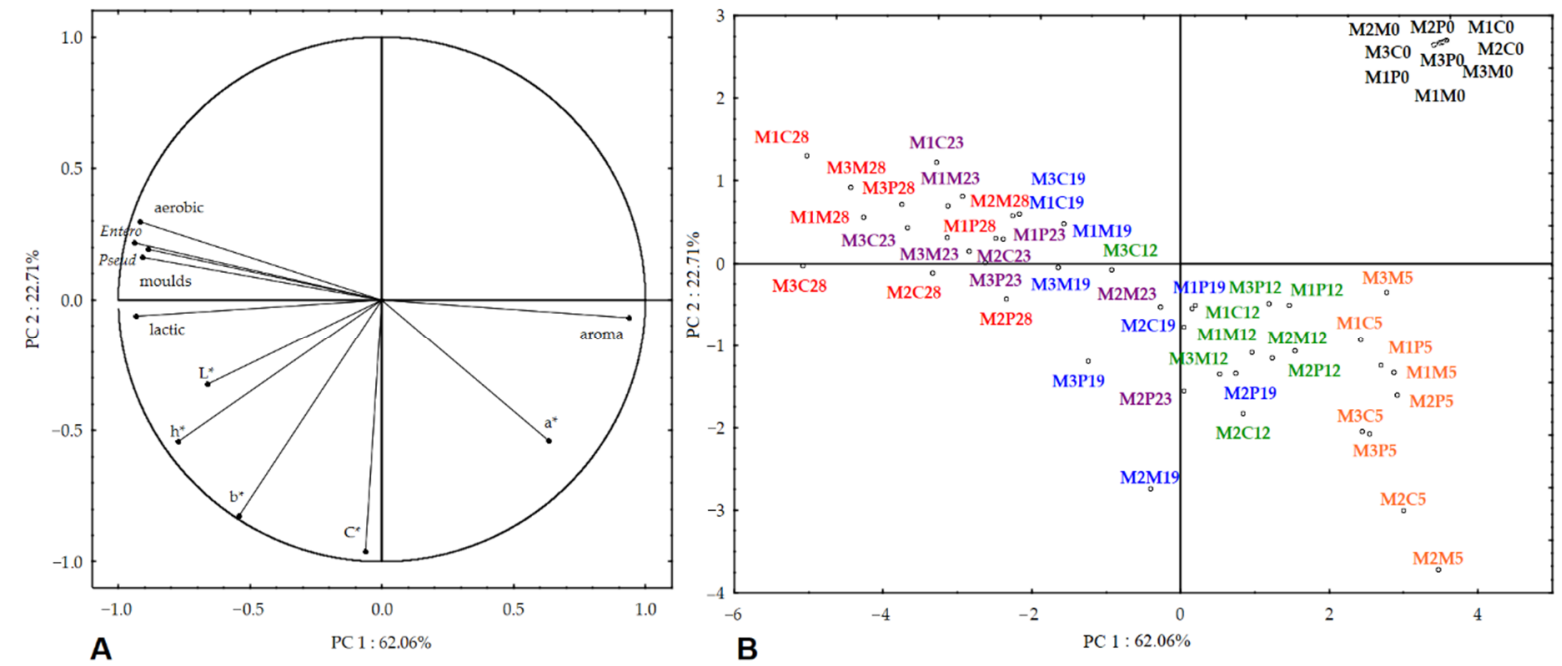

Figure 1. Quality attributes of pork with lysozyme packaged in modified atmosphere: (A): aerobic: aerobic plate count, Entero: Enterobacteriaceae, Pseudo: Pseudomonas, lactic: lactic acid bacteria, moulds: moulds and yeasts; (B): M1-65:25:10 $\mathrm{O}_{2}: \mathrm{CO}_{2}: \mathrm{N}_{2}, \mathrm{M} 2$ - 50:40:10 $\mathrm{O}_{2}: \mathrm{CO}_{2}: \mathrm{N}_{2}, \mathrm{M} 3-80: 20 \mathrm{O}_{2}: \mathrm{CO}_{2} ; \mathrm{C}$-control, M-monomer, P-modified lysozyme.

PC1 was positively correlated with the parameter of colour $\mathrm{a}^{*}$ and aroma, but it was negatively correlated with the counts of aerobic bacteria, Pseudomonas, Enterobacteriaceae, 
yeasts and moulds, lactic acid bacteria, and $\mathrm{L}^{*}$ and $\mathrm{b}^{*}$ parameters. From all the variables which are related to PC1, the strongest factor loadings were noted for Pseudomonas, being -0.94 , and for aroma 0.94. Bacterial count and aroma are on the opposite sides on PC1, which means that there are negative correlations between them. Variables of $b^{*}$ and $C^{*}$ are strongly related to PC2 ( -0.82 and -0.96 respectively). Figure $1 \mathrm{~B}$ shows the PC1 and PC2 values for the samples packaged in the air and modified atmosphere with the lysozyme, depending on the storage time. During the storage the negative PC1 values tended to increase due to the increasing count of microorganisms and the deterioration of the product odour. Both after 23 and 28 days of meat storage the highest $\mathrm{PC} 1$ values were recorded for the samples packaged in modified atmosphere $\mathrm{M} 2\left(50 \% \mathrm{O}_{2}, 40 \% \mathrm{CO}_{2}, 10 \% \mathrm{~N}_{2}\right)$ with modified lysozyme (Figure 1B). This result indicates that both modified lysozyme and carbon dioxide limited the unfavourable changes deteriorating the quality of meat during storage.

\section{Conclusions}

The use of an atmosphere with diversified gas composition and lysozyme considerably extended the shelf life of pork. The combination of the atmosphere with the highest content of carbon dioxide and modified lysozyme resulted in the best effect. This strategy extended the shelf life by more than $20 \%$ increase, as compared with the control sample without lysozyme, packaged in an atmosphere of 50:40:10 $\mathrm{O}_{2}: \mathrm{CO}_{2}: \mathrm{N}_{2}$. The applied forms of lysozyme did not have negative influence on the meat colour parameters. The sample with modified lysozyme was given the highest score for aroma, regardless of the type of atmosphere. The study showed that modified lysozyme exhibited antimicrobial activity not only under model conditions. During the storage of MAP-treated meat modified lysozyme produced the antimicrobial effect despite the possible protection of bacteria by the meat components and their interaction with the enzyme. Lysozyme as a natural enzyme with antimicrobial properties can be used not only for the packaging of meat and meat products but also for other food products. Future research will show whether the modified lysozyme loaded films will extend the shelf life of food products. So far, the properties of the native form of lysozyme have been used, but its activity is limited to Gram-positive bacteria. The results showed that modified lysozyme was more effective against the group of bacteria under analysis than the monomer, which means it can be used for food preservation.

Author Contributions: Conceptualization, R.C.-R. and G.L.; methodology, R.C.-R.; software, Ł.T.; validation, E.R.-K., T.S., and G.L.; formal analysis, G.L.; investigation, R.C.-R., T.S., and Ł.T.; resources, A.B.; data curation, A.B.; writing—original draft preparation, R.C.-R.; writing-review and editing, T.S.; visualization, Ł.T.; supervision, R.C.-R.; project administration, A.B.; funding acquisition, R.C.-R. All authors have read and agreed to the published version of the manuscript.

Funding: Publication was cofinanced within the framework of the Polish Ministry of Science and Higher Education's program: "Regional Initiative Excellence" in the years 2019-2022 (No.005/RID/2018/ 2019)", financing amount 12,000,000 PLN.

Institutional Review Board Statement: Not applicable.

Informed Consent Statement: Not applicable.

Data Availability Statement: Not applicable.

Conflicts of Interest: The authors declare no conflict of interest.

\section{References}

1. Gill, A.O.; Holley, R.A. Inhibition of bacterial growth on ham and bologna by lysozyme, nisin and EDTA. Food Res. Int. 2000, 33, 83-91. [CrossRef]

2. Tiwari, B.K.; Valdramidis, K.V.P.; O’Donnell, C.P.; Muthukumarappan, K.; Bourke, P.; Cullen, P.J. Application of natural antimicrobials for food preservation. J. Agric. Food Chem. 2009, 57, 5987-6000. [CrossRef] [PubMed]

3. Ntzimani, A.G.; Giatrakou, V.I.; Savvaidis, I.N. Combined natural antimicrobial treatments on a ready-to-eat poultry product stored at 4 and $8{ }^{\circ}$ C. Poult. Sci. 2011, 90, 880-888. [CrossRef] 
4. Lucera, A.; Costa, C.; Conte, A.; Del Nobile, M.A. Food applications of natural antimicrobial compounds. Front. Microbiol. 2012, 3 , 1-13. [CrossRef] [PubMed]

5. Syngai, G.G.; Ahmed, G. Chapter 11. Lysozyme: Natural antimicrobial enzyme of interest in food applications. In Enzymes in Food Biotechnology; Kuddus, M., Ed.; Akademic Press: Cambridge, MA, USA, 2019; pp. 169-179.

6. Costa, C.; Lucera, A.; Conte, A.; Zambrini, A.V.; Del Nobile, M.A. Technological Strategies to preserve burrata cheese quality. Coatings 2017, 7, 97. [CrossRef]

7. Wu, T.; Jiang, Q.; Wu, D.; Hu, Y.; Chen, S.; Ding, T.; Ye, X.; Liu, D.; Chen, J. What is new in lysozyme research and its application in food industry? Rev. Food Chem. 2019, 274, 698-709. [CrossRef] [PubMed]

8. Corbo, M.R.; Bevilacqua, A.; Campaniello, D.; D'Amato, D.; Speranza, B.; Sinigaglia, M. Prolonging microbial shelf-life of foods through the use of natural compounds and non-thermal approaches-a review. Int. J. Food Sci. Technol. 2009, 44, $223-241$. [CrossRef]

9. Silvetti, T.; Morandi, S.; Hintersteiner, M.; Brasca, M. Use of hen egg white lysozyme in the food industry. In Egg Innovations and Strategies for Improvements; Hester, P.Y., Ed.; Academic Press: London, UK, 2017; pp. 233-242.

10. Ibrahim, H.R.; Higashiguchi, S.; Juneja, L.R.; Kim, M.; Yamamoto, T. A structural phase of heat-denatured lysozyme with novel antimicrobial action. J. Agric. Food Chem. 1996, 44, 1416-1423. [CrossRef]

11. Masschalck, B.; Michiels, C.W. Antimicrobial properties of lysozyme in relation to foodborne vegetative bacteria. Crit. Rev. Microbiol. 2003, 29, 191-214. [CrossRef] [PubMed]

12. Cegielska-Radziejewska, R.; Lesnierowski, G.; Szablewski, T.; Kijowski, J. Physico-chemical properties and antibacterial activity of modified egg white-lysozyme. Eur. Food Res. Technol. 2010, 231, 959-964. [CrossRef]

13. Aminlari, L.; Hashemi, M.M.; Aminlari, M. Modified lysozyme as novel broad spectrum natural antimicrobial agents in foods. J. Food Sci. 2004, 79, 1077-1089. [CrossRef] [PubMed]

14. Mangalassary, S.; Han, I.; Rieck, J.; Acton, J.; Dawson, P. Effect of combining nisin and/or lysozyme with in-package pasteurization for control of Listeria monocytogenes in ready-to-eat turkey bologna during refrigerated storage. Food Microbiol. 2008, 25, 866-870. [CrossRef] [PubMed]

15. Mastromatteo, M.; Conte, A.; Del Nobile, M.A. Combined use of modified atmosphere packaging and natural compounds for food preservation. Food Eng. Rev. 2010, 2, 28-38. [CrossRef]

16. Zhou, G.H.; Xu, X.L.; Liu, Y. Preservation technologies for fresh meat-A review. Meat Sci. 2010, 86, 119-128. [CrossRef] [PubMed]

17. Zhang, M.; Meng, X.; Bhandari, B.; Fang, Z.; Chen, H. Recent application of modified atmosphere packaging (MAP) in fresh and fresh-cut foods. Food Rev. Int. 2015, 31, 172-193. [CrossRef]

18. McMillin, K. Where is MAP Going? A review and future potential of modified atmosphere packaging for meat. Meat Sci. 2008, 80, 43-65. [CrossRef] [PubMed]

19. Kaewprachu, P.; Oskako, K.; Benjakul, S.; Rawdkuen, S. Quality attributes of minced pork wrapped with catechin-lysozyme incorporated gelatin film. Food Packag. Shelf Life 2015, 3, 88-96. [CrossRef]

20. Huang, T.; Qian, Y.; Wei, J.; Zhou, C. Polymeric antimicrobial food packaging and its applications. Polymers 2019, 11, 560. [CrossRef]

21. Polish Committee for Standarization. Meat and Meat Products—Determination of Free Fat Content; PN-ISO 1444:2000; Polish Committee for Standarization: Warsaw, Poland, 2000. (In Polish)

22. Lesnierowski, G. Physicochemical Methods of Modification and Measurement of Lysozyme Activity. Postdoctoral Thesis, Poznan University of Life Sciences, Warsaw, Poland, 2007. (In Polish)

23. Laemmli, U.K. Cleavage of structural proteins during the assembly of the head of bacteriophage T4. Nature 1970, 227, 680-688. [CrossRef]

24. Kato, A.; Nakai, S. Hydrophobicity determined by a fluorescence probe method and its correlation with surface properties of proteins. Biochim. Biophys. Acta 1980, 624, 13-17. [CrossRef]

25. Li-Chan, E.; Nakai, S.; Wood, D.F. Hydrophobicity and solubility of meat proteins and their relationship to emulsifying properties. J. Food Sci. 1984, 49, 345-350. [CrossRef]

26. ISO. Microbiology of the Food Chain-Horizontal Method for the Enumaration of Microorganisms_Part 1: Colony Count at 30 Degrees C by the Pour Plate Technique Microbiology of the Food Chain-Horizontal Method for the Enumaration of Micro; ISO 4833-1:2013; Polish Committee for Standarization: Warsaw, Poland, 2013.

27. ISO. Microbiology of the Food Chain—Horizontal Method for the Detection and Enumeration of Enterobacteriaceae—Part 2: Colony Count Technique; ISO 21528-2:2017; Polish Committee for Standarization: Warsaw, Poland, 2013.

28. ISO. Microbiology of Food and Animal Feeding Stuffs-Horizontal Method for the Enumeration of Mesophilic Lactic Acid Bacteria-Colony Count Technique at 30 Degrees C; ISO 15214-2:1998; Polish Committee for Standarization: Warsaw, Poland, 2013.

29. ISO. Meat and Meat Products-Enumeration of Presumptive Pseudomonas spp.; ISO 13720:2010; Polish Committee for Standarization: Warsaw, Poland, 2013.

30. Polish Committee for Standarization. Sensory Analysis-General Guidelines for the Selection, Training and Monitoring of Assessors and Expert Sensory Assessors; PN-EN ISO 8586:2014-03; Polish Committee for Standarization: Warsaw, Poland, 2014.

31. Commision Internationale de l'Eclairage (CIE). Recommendations on Uniform Color Spaces, Color Difference Equation, Psychometric Color Terms; CIE Publication No. 15; CIE: Paris, France, 1978; pp. 8-12.

32. AMSA. Meat Color Measurements Quidelines; American Meat Science Association: Champaign, IL, USA, $2012 ;$ p. 136. 
33. Cegielska-Radziejewska, R.; Lesnierowski, G.; Kijowski, J. Antibacterial activity of hen egg white lysozyme modified by thermochemical technique. Eur. Food Res. Technol. 2009, 228, 841-845. [CrossRef]

34. Lesnierowski, G.; Kijowski, J.; Cegielska-Radziejewska, R. Ultrafiltration-modified chicken egg white lysozyme and its antibacterial action. Int. J. Food Sci. Technol. 2009, 44, 305-311. [CrossRef]

35. Cegielska-Radziejewska, R.; Szablewski, T. Effect of modified lysozyme on the microflora and sensory attributes of ground pork. J. Food Prot. 2013, 76, 338-342. [CrossRef] [PubMed]

36. Viana, E.S.; Gomide, L.A.M.; Vanetti, M.C.D. Effect of modified atmospheres on microbiological, color and sensory properties of refrigerated pork. Meat Sci. 2005, 71, 696-705. [CrossRef]

37. Lukic, M.; Petronijevic, R.; Petrovic, Z.; Karan, D.; Djordjevic, V.; Trbovic, D.; Parunovic, N. Effects of different gas composition on the color estimations of MAP packaged pork chops. Procedia Food Sci. 2015, 5, 168-171. [CrossRef]

38. Labadie, J. Consequences of packaging on growth. Meat is an ecological niche. Meat Sci. 1999, 52, 299-305. [CrossRef]

39. Cannarsi, M.; Baiano, A.; Sinigaglia, M.; Ferrara, L.; Baculo, R.; Del Nobile, M.A. Use of nisin, lysozyme and EDTA for inhibiting microbial growth in chilled buffalo meat. Int. J. Food Sci. Technol. 2008, 43, 573-578. [CrossRef]

40. Rao, M.S.; Chander, R.; Sharma, A. Synergistic effect of chitooligosaccharides and lysozyme for meat preservation. Food Sci. Technol. 2008, 41, 1995-2001. [CrossRef]

41. Djordjevic, J.; Boskovic, M.; Dokmanovic, M.; Brankovic Lazic, I.; Ledina, T.; Suvajdzic, B.; Baltic, M.Z. Vacuum and modified atmosphere packaging effect on Enterobacteriaceae behaviour in minced meat. J. Food Process. Preserv. 2017, 41, 1-7. [CrossRef]

42. Malicki, A.; Trziszka, T.; Szpak, M.; Źródłowska-Danek, J. Research using lysozyme and sodium acetate in order to extend the durability of poultry meat. Vet. Med. 2010, 66, 699-701.

43. Cegielska-Radziejewska, R.; Szablewski, T. Use of thermochemically modified lysozyme to extend the shelf-life of food. Chem. Ind. 2014, 4, 542-546.

44. Hur, S.J.; Jin, S.K.; Park, J.H.; Jung, S.W.; Luy, H.J. Effect of modified atmosphere packaging on quality characteristics of low grade beef during cold storage. Asian Australas J. Anim. Sci. 2013, 26, 1781-1789. [CrossRef] [PubMed]

45. Hu, J.; Wang, X.; Xiao, Z.; Bi, W. Effect of chitosan nanoparticles loaded with cinnamon essentials oil on the quality of chilled pork. LWT Food Sci. Technol. 2015, 63, 519-526. [CrossRef]

46. Lorenzo, J.M.; Sineiro, J.; Amado, I.R.; Franco, D. Influence of natural extracts on the shelf life of modified atmosphere-packaged pork patties. Meat Sci. 2014, 96, 526-534. [CrossRef] [PubMed]

47. Muzolf-Panek, M.; Kaczmarek, A.; Tomaszewska-Gras, J.; Cegielska-Radziejewska, R.; Majcher, M. Oxidative and microbiological stability of raw ground pork during chilled storage as affected by plant extracts. Int. J. Food Prop. 2019, 22, 111-129. [CrossRef]

48. Nattress, F.M.; Baker, L.B. Effects of treatment with lysozyme and nisin on the microflora and sensory properties of commercial pork. Int. J. Food Microbiol. 2003, 85, 259-267. [CrossRef]

49. Mancini, R.A.; Hunt, M.C. Current research in meat color. Meat Sci. 2005, 71, 100-121. [CrossRef] [PubMed]

50. Nattress, F.M.; Yost, C.K.; Baker, L.P. Evaluation of the ability of lysozyme and nisin to control meat spoilage bacteria. Int. J. Food Sci. Microbiol. 2001, 70, 111-119. [CrossRef]

51. Morsy, K.; Elsabagh, R.; Trinetta, V. Evaluation of novel synergistic antimicrobial activity of nisin, lysozyme, EDTA nanoparticles and/or ZnO nanoparticles to control foodborne pathogens on minced beef. Food Control 2018, 92, 249-254. [CrossRef]

52. Rollini, M.; Nielsen, T.; Musati, A.; Limbo, S.; Piergiovanni, L.; Munoz, P.H.; Gavara, R. Antimicrobial performance of two different packaging materials on microbiological quality of fresh salomon. Coatings 2016, 6, 6. [CrossRef]

53. Cegielska-Radziejewska, R.; Leśnierowski, G.; Kijowski, J.; Szablewski, T.; Zabielski, J. Effect of treatment with lysozyme and its polimers on microflora and sensory properties of chilled chicken breast muscles. J. Vet. Res. 2009, 53, 455-461. 